\title{
Millard Meiss, American Art History, and Conservation
}

A member of the art history generation from the golden age of the 1920s and 1930s, Millard Meiss (1904-1975) developed a new and multi-faceted methodological approach.

This book lays the foundation for a reassessment of this key figure in post-war American and international art history. The book analyses his work alongside that of contemporary art historians, considering both those who influenced him and those who were receptive to his research. Jennifer Cooke uses extensive archival material to give Meiss the critical consideration that his extensive and important art historical, restoration and conservation work deserves.

This book will be of interest to scholars in art history, historiography and heritage management and conservation.

Jennifer Cooke is a researcher in History of Art Criticism and Museum Studies at the University of Turin.

Cover image: Photo of Millard Meiss by Hans Namuth (1961), Millard Meiss Papers, circa 1918-circa 1977, bulk 1950-1975, Archives of American Art, Smithsonian Institution. 


\section{Studies in Art Historiography \\ Series Editor: Richard Woodfield \\ University of Birmingham}

The aim of this series is to support and promote the study of the history and practice of art historical writing focusing on its institutional and conceptual foundations, from the past to the present day in all areas and all periods. Besides addressing the major innovators of the past it also encourages re-thinking ways in which the subject may be written in the future. It ignores the disciplinary boundaries imposed by the Anglophone expression 'art history' and allows and encourages the full range of enquiry that encompasses the visual arts in its broadest sense as well as topics falling within archaeology, anthropology, ethnography and other specialist disciplines and approaches.

For a full list of titles in this series, please visit https://www.routledge.com/Studies-i n-Art-Historiography/book-series/ASHSER2250

Comparativism in Art History

Edited by Jaś Elsner

Constructing the Viennese Modern Body

Art, Hysteria and the Puppet

Nathan J. Timpano

Messerschmidt's Character Heads

Maddening Sculpture and the Writing of Art History

Michael Yonan

Time in the History of Art

Temporality, Chronology, and Anachrony

Edited by Dan Karlholm and Keith Moxey

New Narratives of Russian and East European Art

Between Traditions and Revolutions

Edited by Galina Mardilovich and Maria Taroutina

Making Art History in Europe after 1945

Edited by Noemi de Haro-García, Patricia Mayayo and Jesús Carrillo

Millard Meiss, American Art History, and Conservation

From Connoisseurship to Iconology and Kulturgeschichte

Jennifer Cooke 


\section{Millard Meiss, American Art History, and Conservation}

From Connoisseurship to Iconology and Kulturgeschichte

Jennifer Cooke 
First published 2021

by Routledge

52 Vanderbilt Avenue, New York, NY 10017

and by Routledge

2 Park Square, Milton Park, Abingdon, Oxon, OX14 4RN

Routledge is an imprint of the Taylor \& Francis Group, an informa business

(C) 2021 Taylor \& Francis

The right of Jennifer Cooke to be identified as author of this work has been asserted by them in accordance with sections 77 and 78 of the Copyright, Designs and Patents Act 1988.

All rights reserved. No part of this book may be reprinted or reproduced or utilised in any form or by any electronic, mechanical, or other means, now known or hereafter invented, including photocopying and recording, or in any information storage or retrieval system, without permission in writing from the publishers.

Trademark notice: Product or corporate names may be trademarks or registered trademarks, and are used only for identification and explanation without intent to infringe.

Library of Congress Cataloging-in-Publication Data

Names: Cooke, Jennifer, 1983- author. I Cooke, Jennifer, 1983- Millard Meiss.

Title: Millard Meiss, American art history, and conservation: from connoisseurship to iconology and Kulturgeschichte/Jennifer Cooke.

Other titles: Millard Meiss. English

Description: New York: Routledge, 2021. I Originally published in Italy in

2015 by Ledizioni as Millard Meiss: tra connoisseurship, iconologia e

Kulturgeschichte. I Includes bibliographical references and index.

Identifiers: LCCN 2020025272 (print) I LCCN 2020025273 (ebook) |

ISBN 9780367138349 (hardback) I ISBN 9780367138356 (ebook)

Subjects: LCSH: Meiss, Millard. I Art-Historiography. |

Historiography-United States-History-20th century.

Classification: LCC N7483.M45 C6613 2021 (print) I

LCC N7483.M45 (ebook) I DDC 709--dc23

LC record available at https://lccn.loc.gov/2020025272

LC ebook record available at https://ccn.loc.gov/2020025273

ISBN: 978-0-367-13834-9 (hbk)

ISBN: 978-0-367-13835-6 (ebk)

Typeset in Sabon

by Deanta Global Publishing Services, Chennai, India 


\section{Contents}

Illustrations and Illustration Credits viii

Preface

Acknowledgements

List of Abbreviations

xii

Cited Works by Millard Meiss

xiii

xiv

Introduction

Bibliography 4

1 Two Generations of American Connoisseurs

Richard Offner's Scientific Connoisseurship 5

The Two Cartographers 6

The Foundations for a Science of Connoisseurship 8

A Short History of Meiss's Attributions 10

The First Thorny Problems of Ugolino Lorenzetti and

Francesco Traini 10

'Scusi, ma sempre Duccio': The Case of the Frick Flagellation 17

'The World Clearly Wants Giotto to Be the Author':

The Assisi Debate 26

The Sharp Eye of a Connoisseur and the Acute Mind of a Scientist 34 Bibliography 36

2 The Far Side of the Moon: Erwin Panofsky's Iconology

Panofsky Arrives in the United States 47

Towards an American-style Iconology 49

A Casual but Illuminating Conversation 57

The 'Synthronismus' 65

'Von Haus zu Haus' 68

The Extent of His Influence, the Weight of His Authority and the

Solidity of His Reign 69 
vi Contents

Panofskyan Pathways 73

Arnolfini's Hat 73

Iconology of Light 76

'Oology May Qualify as a Branch of Iconology' 78

Meissian Slumber 81

Bibliography 84

3 Kulturgeschichte or Social History of Art?

Reviewing Antal 98

The 'Pest Book' and Post-war Scholarship 100

'One of the Most Original and Sound Works in the History of Art' 100

The Historian's View: Yves Renouard, Hans Baron and Roberto S. Lopez 108

The Habitus Does Not Make the Art Bishop: Berenson and Panofsky 110

Ragghianti's Attack and the Italian Response 114

'A Book That Ought to Have Been Known in Italy Not Only by

Scholars Alone': The Complications of a Translation 117

'The Holes in the Meissian Model Have Grown Larger with Each

Passing Year' 123

The History of Culture after the Black Death 125

Bibliography 128

4 The Technical Study of Art

Harvard's Art Laboratory 138

'America as Guardian of the World's Art Treasures': The American

Committee for the Restoration of Italian Monuments 139

ACRIM's Projects of Restoration 143

The Involvement of Bernard Berenson 145

Meiss's Studies on Mural Paintings 147

The Trigger-Happy Detachment of Frescoes 147

The Giornate in Assisi with Leonetto Tintori 150

A Book on the History of Art Techniques 154

American Aid after the Flood 157

'An Acute Case of CRIAmania' 157

Ugo Procacci, Tintori's Brigata and Italian

'Stubborn Rivalries' 162

From The Great Age of Fresco to Firenze Restaura 166

Bibliography 171 
A Connoisseur's Early Impressions of Italy 182

An American Panofsky and a Candid Iconologist 184

Meiss's Associates 187

Longhi and Salmi 187

The Soprintendenti's Circle 191

A True Gentleman from the 19th Century 194

The Champion of Iconology and History of Culture, or Our Man in Italy 197

When Princeton Mostly Spoke Italian 200

A Three-Faced Man 201

Bibliography 204

Index 


\section{Illustrations and Illustration Credits}

Where possible, the images in this book were purposefully chosen from Federico Zeri's personal photo collection to illustrate the kind of visual reference that Millard Meiss would have used.

1.1 Francesco Traini, Triptych of St Dominic (central panel), 1344-1345, oil on panel, $175 \times 74 \mathrm{~cm}$, Pisa, Museo Nazionale di San Matteo

[Bologna, Fototeca Federico Zeri, inv. no. 23689]

1.2 Francesco Traini, Madonna and Child with St Anne, 1340-1345, tempera on wood panel transferred to pressed wood panel, $84.9 \times 56 \mathrm{~cm}$, Princeton, Princeton University Art Museum [Bologna, Fototeca Federico Zeri, inv. no. 23683]

1.3 Lippo Memmi, Glorification of St Thomas Aquinas, 1323, tempera on panel, $375 \times 258 \mathrm{~cm}$, Pisa, Church of Santa Caterina d'Alessandria [Bologna, Fototeca Federico Zeri, inv. no. 21415]

1.4 Buonamico Buffalmacco, Triumph of Death, ca. 1338-1339, fresco, Pisa, Camposanto [Bologna, Fototeca Federico Zeri, inv. no. 23614]

1.5 Buonamico Buffalmacco, St George and the Dragon, ca. 1350, fresco, Parma, Baptistry [Bologna, Fototeca Federico Zeri, inv. no. 23608]

1.6 Cenni di Pepo (known as Cimabue), Flagellation of Christ (cleaned and retouched), ca. 1280, tempera on poplar panel, $24.7 \times 20 \mathrm{~cm}$, New York, Frick Art Collection [Bologna, Fototeca Federico Zeri, inv. no. 9960]

2.1 Giovanni Bellini (attr.), Portrait of Jacopo Antonio Marcello, ca. 1453, Paris, Bibliothèque Nationale, MS 940 Passio Mauritii et sotiorum ejus, f. $38 \mathrm{v}$

.1 Andrea Bonaiuti (known as Andrea da Firenze), Spanish Chapel, 1366-1368, view of the interior, Florence, Santa Maria Novella [Bologna, Fototeca Federico Zeri, inv. no. 16066]

3.2 Andrea di Cione (known as Orcagna), Triumph of Death (fragment), ca. 1348, fresco, Florence, Santa Croce [Bologna, Fototeca Federico Zeri, inv. no. 15089]

3.3 Lippo Memmi, Crucifixion, ca. 1340, fresco, San Gimignano, Collegiata di Santa Maria Assunta [Bologna, Fototeca Federico Zeri, inv. no. 21507]. Authorised by the Soprintendenza Archeologia Belle Arti e Paesaggio di Siena Grosseto e Arezzo 
5.1 Cesi Master, Assumption of the Virgin (central panel of the Stella Altarpiece), 1308, tempera on wood, $191 \times 175.5 \mathrm{~cm}$, St.-Jean-Cap-Ferrat, Villa \& Gardens Ephrussi de Rothschild [Bologna, Fototeca Federico Zeri, inv. no. 30907]

\section{Photo credits}

(C) Archives of American Art, Smithsonian Institution

(C) Fototeca della Fondazione Federico Zeri, Bologna

(C) Bibliothèque Nationale, Paris 


\section{Preface}

Discussing Millard Meiss's studies, his 'modes of approach to works of art', his 'methods of investigation' and his 'critical vision', is the purpose of this book. ${ }^{1}$ Originally a doctoral thesis defended in 2013, subsequently published in an abridged form in Italian in 2015, this research on the American art historian is now finally brought to the English-speaking readership. ${ }^{2}$ Being a self-translation, its ties to the original are those of a belle infidele, and the hiatus that occurred made a considerable revision of both content and reference literature necessary. The chapters are organised according to Meiss's methodological axes, i.e. connoisseurship, iconology, Kulturgeschichte and the technical study of art, not to further a somewhat schizophrenic reception of his works, but to show on the contrary how these aspects are deeply interconnected in his approach. The final part addresses his critical fortune from a specific perspective, that of Italian scholarship, not only because his studies were primarily concerned with Italian (or Tuscan) art and his personal relations with many Italian art historians, but mainly because the impact he exerted in Italy may be useful to understand the reception of his scholarly work in a broader framework. The reasons for what I termed an Italian 'Meiss-fortune' may be found not only in connoisseurs' conflicts, but also in a widespread myopia towards an approach that combined formal analysis with the interpretation of meaning - a 'slippery word' used by Panofsky for the intrinsic significance of the work of art. Consequently, Meiss was in the best-case scenario identified with the iconological drift of American scholarship, or in the worst, assimilated with an accessory sociological interpretation of art. On the other hand, sharing Panofsky's scepticism towards theory -'a rather suspect concept, tainted as it was by theories of race (which classified human beings hierarchically) and theories of quality (which classified works of art hierarchically)',

1 Borrowing David Rosand's words: 'If his own scholarship was exemplary, still more so was his critical vision. He never lost sight of what was important. His inquiry began with, was inspired by, the work of art. Even as he located an image in its historical and art historical contexts with convincing exactness, he insisted that we respect it for itself, for its intrinsic aesthetic and expressive qualities', in: Rosand $1980,447$.

2 Cooke 2015. 
Preface xi

as Irvin Lavin described $\mathrm{it}^{3}$ - Meiss did very little to defend or convey his method(s). As a case in point, when asked to define his approach, he replied with his proverbial understatement:

My work is related to that of scientists - you try on hats, you really put the hat on the object. The important thing is to get one that fits. ${ }^{4}$

\section{Bibliography}

Cooke, J., Millard Meiss: tra Connoisseurship, Iconologia e Kulturgeschichte (Milan: Ledizioni, 2015).

Glueck, G., 'Art History Colleagues Honor Millard Meiss', in: The New York Times (15 April 1974), 38.

Lavin, I., 'The Crisis of “Art History”', in: The Art Bulletin LXXVIII, 1 (1996), 13-15.

Rosand, D., 'Studies in Late Medieval and Renaissance Painting in Honor of Millard Meiss by Irving Lavin; John Plummer', in: Renaissance Quarterly XXXIII, 3 (1980), 446-448.

3 Lavin was referring to the condition of art history in the United States in the 1950s, and further he wrote: 'Meaning, in fact, links the formal to the conceptual revolution of my contemporaries' (Lavin 1996, 13). Incidentally, Irving Lavin (1927-2019) was chosen by Meiss for his 'wide variety of methods and approaches' as his successor at Princeton (AAA, MMP. Letter of recommendation by Millard Meiss, August 1972).

4 Quoted in: Glueck 1974. 


\section{Acknowledgements}

My deepest gratitude goes to the late Gianni C. Sciolla, who first introduced me to American art historiography and directed my studies to Millard Meiss back in 2008, and to Franca Varallo for her unfailing support and advice throughout the last decade. A huge thank you goes to Richard Woodfield for welcoming this book in the Historiography of Art series and his invaluable feedback in the writing process. Many dedicated and enthusiastic librarians and research staff have helped me put together this study. Amongst the people I would like to thank are Audrey Avenel, Carla Bernardini, Giuliano Berti Arnoaldi Veli, Marisa Bourgoin, Monica Cavicchi, Silvia Chiodo, Susan Chore, Marcella Culatti, Ilaria Della Monica, Loisann Dowd White, Ester Fasini, Emanuela Fiori, Sergio La Porta, Luca Lenzini, Julie Ludwig, Elisabetta Nencini, Mirjo Salvini, Giuseppa Saccaro del Buffa and Carla Zarrilli. My thoughts also go to Irving Lavin, or 'IL' as some of us will remember him, and to his memory I dedicate this book. Lastly, my family and my loving partner Michael, many friends and colleagues and a cat named Millard, have all played a part in this endeavour. To them I will always be indebted. 


\section{List of Abbreviations}

Here follows a list of abbreviations for the archive collections consulted.

AAA, MMP Archives of American Art, Smithsonian Institution, Millard Meiss Papers, ca. 1918-ca. 1977, bulk 1950-1975

APCG Bologna, Archivio Privato Cesare Gnudi

APEB Rome, Archivio Privato Eugenio Battisti

ASTo Turin, Archivio di Stato

BB Settignano, Biblioteca Berenson, Villa I Tatti - The Harvard University Center for Italian Renaissance Studies, courtesy of the President and Fellows of Harvard College

BMBP Bernard and Mary Berenson Papers

CRIA VIT Committee to Rescue Italian Art, Papers: Villa I Tatti

PITTI Committee to Rescue Italian Art, Papers: Palazzo Pitti Office

FARLA, FC New York, Frick Art Reference Library Archives, The Frick Collection

INHA Paris, Institut National d'Histoire de l'Art

LAELT Figline di Prato, Laboratorio per Affresco Elena e Leonetto Tintori

PGRI, JHP Los Angeles, The Paul J. Getty Research Institute, Julius S. Held Papers

UNISI, BLF Siena, Università degli Studi di Siena, Biblioteca di Lettere e Filosofia

The mammoth volumes of Erwin Panofsky's correspondence edited by Dieter Wuttke that are frequently referred to will be abbreviated as follows:

Panofsky 2001 E. Panofsky, Korrespondenz 1910 bis 1936, vol. I, ed. by D. Wuttke (Wiesbaden: Harrassowitz, 2001)

Panofsky 2003 E. Panofsky, Korrespondenz 1937 bis 1949, vol. II, ed. by D. Wuttke (Wiesbaden: Harrassowitz, 2003)

Panofsky 2006 E. Panofsky, Korrespondenz 1950 bis 1956, vol. III, ed. by D. Wuttke (Wiesbaden: Harrassowitz, 2006)

Panofsky 2008 E. Panofsky, Korrespondenz 1957 bis 1961, vol. IV, ed. by D. Wuttke (Wiesbaden: Harrassowitz, 2008)

Panofsky 2011 E. Panofsky, Korrespondenz 1962 bis 1968, vol. V, ed. by D. Wuttke (Wiesbaden: Harrassowitz, 2011) 


\section{Cited Works by Millard Meiss}

1931

'Ugolino Lorenzetti', in: The Art Bulletin XIII, 3 (1931), 376-397.'

1933

'The Problem of Francesco Traini', in: The Art Bulletin XV, 2 (1933), 97-173.

1935

'Un dessin par le Maître des Grandes Heures de Rohan', in Gazette des Beaux-Arts XIII, I (1935), 65-75.

1936

'Bartolomeo Bulgarini altrimenti detto "Ugolino Lorenzetti”?', in: Rivista d'Arte XVIII, 2 (1936), 113-136. (a)

'The Madonna of Humility', in: The Art Bulletin XVIII, 4 (1936), 435-464. (b)

1937

'Fresques italiennes cavallinesques et autres à Béziers', in: Gazette des Beaux-Arts XVIII (1937), 275-286.

1938

'Grace Frank and Dorothy Miner, Proverbes en rimes', in: The Art Bulletin XX, 3 (1938), 332-333.

1941

'A Documented Altarpiece by Piero della Francesca', in: The Art Bulletin XXIII, 1 (1941), 53-68.

\section{4}

'A Statement on the Place of the History of Art in the Liberal Arts Curriculum', in: College Art Journal III (1944), 82-87.

1 For a complete bibliography of Meiss's works up to 1977, refer to Irving Lavin and John Plummers (eds.), Studies in Late Medieval and Renaissance Painting in Honor of Millard Meiss, 2 vols. (New York: New York University Press, 1977), xiii-xx. 
1945

'Light as Form and Symbol in Some Fifteenth-Century Paintings', in: The Art Bulletin XXVII, 3 (1945), 175-181; republ. in: Meiss 1976, 3-18.

1946

'Italian Primitives at Konopiště', in: The Art Bulletin XXVIII, 1 (1946), 1-16. (a)

'War's Toll of Italian Art', in: Magazine of Art XXXIX (1946), 240-241. (b)

1947

'A Note on Piero della Francesca's St. Augustine Altarpiece', in: The Burlington Magazine LXXXIX, 535 (1947), 286.

1948

'Conditions of Historic Art and Scholarship in Italy', in: College Art Journal VII (1948), 199-202. (a)

'Enzo Carli, Le sculture del Duomo di Orvieto', in: Magazine of Art XLI (1948), 321. (b)

1949

'Frederick Antal, Florentine Painting and Its Social Background', in: The Art Bulletin XXXI, 2 (1949), 143-150.

1951

Painting in Florence and Siena after the Black Death. The Arts, Religion and Society in the Mid-Fourteenth Century (Princeton NJ: Princeton University Press, 1951). (a)

'A New Early Duccio', in: The Art Bulletin XXXIII, 2 (1951), 95-103. (b)

1952

" "Nicholas Albergati" and the Chronology of Jan van Eyck's Portraits', in: The Burlington Magazine XCIV, 590 (1952), 137-144. (a)

'Scusi, ma sempre Duccio', in: Paragone III, 27 (1952), 63-64. (b)

'Grete Ring, A Century of French Painting: 1400-1500', in: Magazine of Art XLV (1952), 46. (c)

'Kenneth Clark, Piero della Francesca', in: Magazine of Art XLV, 2 (1952), 93-94. (d) 'Piero della Francesca, Frescoes, with an introduction by Roberto Longhi', in: Magazine of Art XLV, 3, (1952), 141. (e)

1953

'Trecento Scramble', in: The Art Bulletin XXXV, 1 (1953), 52-55.

1954

'A World Jewel-Like and Sparkling. Early Netherlandish Painting: Its Origins and Character', in: The New York Times Book Review (7 March 1954), 5. (a)

“"Ovum Struthionis", Symbol and Allusion in Piero della Francesca's Montefeltro Altarpiece', in: D. Miner (ed.), Studies in Art and Literature for Belle da Costa Greene (Princeton NJ: Princeton University Press, 1954), 92-101; republ. in: Meiss 1976, 105-129. (b) 
'Addendum Ovologicum', in: The Art Bulletin XXXVI, 3 (1954), 221-222. (c)

'George Kaftal, Iconography of the Saints in Tuscan Painting', in: The Art Bulletin XXXVI, 2 (1954), 148-149. (d)

\section{5}

'Nuovi dipinti e vecchi problemi', in: Rivista d'Arte XXX (1955), 107-145. (a)

'Ovum struthionis: Symbol and Allusion in Piero della Francesca's Montefeltro Altarpiece', in: Actes du XVIIe Congrès International d'histoire de l'art, Amsterdam 23-31 July 1952 (The Hague: Imprimerie Nationale des Pays-Bas, 1955), 308-310. (b)

\section{6}

'The Exhibition of French Manuscripts of the XII-XIV Centuries at the Bibliothèque Nationale', in: The Art Bulletin XXXVIII, 3 (1956), 187-196. (a)

'Jan van Eyck and the Italian Renaissance', in L. Venturi (ed.), Venezia e l'Europa, Acts of the 18th International Congress of the History of Art, Venice 12-18 September 1955 (Venice: Casa Editrice Arte Veneta, 1956), 58-69; republ. in: Meiss 1976, 19-35. (b)

'Primitifs italiens à l'Orangerie', in: Revue des Arts VI (1956), 139-148. (c)

1957

Mantegna as Illuminator. An Episode in Renaissance Art, Humanism and Diplomacy (New York: Augustin - Columbia University Press, 1957). (a)

'The Case of the Frick Flagellation', in Journal of the Walters Art Gallery XIX-XX (1956-1957), 43-63. (b)

'Carl Nordenfalk, Kung Pratik's Och Drottning Teoris Jaktbok. Le Livre des Deduis du Roi Modus et la reine Ratio', in: Speculum XXXII, 3 (1957), 594-596. (c)

1959

'Mortality among Florentine Immortals', in: ArtNews LVIII, 4 (1959), 26-29, 46-47, 56-57.

1960

Giotto and Assisi (New York: New York University Press, 1960). (a)

'A Madonna by Francesco Traini', in: Gazette des Beaux-Arts LVI (1960), 49-56. (b) 'The Role of the Art Historian', in Forum Lectures, Forum Art Series, 1960, 1-6. (c) 'Toward a More Comprehensive Renaissance Paleography', in: The Art Bulletin XLII, 2 (1960), 97-112. (d)

1961

De Artibus Opuscula XL. Essays in Honor of Erwin Panofsky, 2 vols. (New York: New York University Press, 1961). (a)

'An Early Lombard Altarpiece', in: S. Bottari (ed.), Studi di Storia dell'arte. Raccolta di saggi dedicati a Roberto Longhi in occasione del suo settantesimo compleanno, in: Arte Antica e Moderna IV (1961), 125-133. (b)

" "Highlands" in the Lowlands', in: Gazette des Beaux-Arts LVII (1961), 273-314; republ. in: Meiss 1976, 36-59. (c) 
1962

with L. Tintori, The Painting of the Life of St. Francis in Assisi, with Notes on the Arena Chapel (New York: New York University Press, 1962). (a)

'Reflections of Assisi: A Tabernacle and the Cesi Master', in: G. de Francovich, A. Marabottini, V. Martinelli et al. (eds.), Scritti di storia dell'arte in onore di Mario Salmi, 3 vols. (Rome: De Luca, 1961-1962), II, 75-111. (b)

1963

Studies in Western Art, Acts of the 20th International Congress of the History of Art, New York 7-12 September 1961, 4 vols. (Princeton NJ: Princeton University Press, 1963). Vol. I: Romanesque and Gothic Art; vol. II: The Renaissance and Mannerism; vol. III: Latin American Art, and the Baroque Period in Europe; vol. IV: Problems of the 19th and 20th Centuries. (a)

'Masaccio and the Early Renaissance: The Circular Plan', in: Studies in Western Art cit., II, 123-145. (b)

'French and Italian Variations on an Early Fifteenth-Century Theme: St. Jerome and His Study', in: Gazette des Beaux-Arts LXII (1963), 147-170. (c)

'Giovanni Bellini's St Francis', in: Saggi e Memorie di Storia dell'Arte III (1963), 11-30. (d) 'A Lost Portrait of Jean de Berry by the Limbourgs', in: The Burlington Magazine CV, 719 (1963), 51-53. (e)

\section{4}

Giovanni Bellini's St. Francis in the Frick Collection (Princeton NJ: Princeton University Press, 1964). (a)

'The Art Bulletin at Fifty', in: The Art Bulletin XLVI, 1 (1964), 1-5. (b)

'The Yates Thompson Dante and Priamo della Quercia', in: The Burlington Magazine CVI, 738 (1964), 403-412. (c)

Painting in Florence and Siena after the Black Death. The Arts, Religion and Society in the Mid-Fourteenth Century (New York: Harper \& Row, 1964). (d)

with L. Tintori, 'Additional Observations on Italian Mural Technique', in: The Art Bulletin XLVI, 3 (1964), 377-380. (e)

\section{5}

'An Illuminated Inferno and Trecento Painting in Pisa', in: The Art Bulletin XLVII, 1 (1965), 21-34.

\section{6}

with T.G. Jones, 'Once Again Piero della Francesca's Montefeltro Altarpiece', in: The Art Bulletin XLVIII, 2 (1966), 203-206; republ. in: Meiss 1976, 130-141. (a)

'Sleep in Venice; Ancient Myths and Renaissance Proclivities', in: Proceedings of the American Philosophical Society CX, 5 (1966), 348-382; republ. in: Meiss 1976, $212-$ 239. (b)

'Letter. Giovanni Bellini's “St Francis"', in: The Burlington Magazine CVIII, 754 (1966), 27. (c)

1967

'Allocation of Funds to January 18, 1967', in: Renaissance Quarterly XX, 1 (1967), 105-106. (a) 
xviii Cited Works by Millard Meiss

Giotto and Assisi (New York: The Norton Library Press, 1967²). (b)

French Painting in the Time of Jean de Berry: The Late Fourteenth Century and the

Patronage of the Duke, 2 vols. (London - New York: Phaidon, 1967). (c)

'Sleep in Venice', in: H. von Einem (ed.), Stil und Überlieferung in der Kunst des Abendlandes, Acts of the 21st International Congress of the History of Art, Bonn 14-19 September 1964, 3 vols. (Berlin: Mann, 1967), III, 271-279. (d)

with L. Tintori, The Painting of The Life of St. Francis in Assisi: With Notes on the Arena Chapel and a 1964 Appendix (New York: The Norton Library Press, $\left.1967^{2}\right)$. (e)

\section{8}

French Painting in the Time of Jean de Berry: The Boucicaut Master (London: Phaidon, 1968). (a)

'Florence and Venice a Year Later (Reports on Scholarship in the Renaissance)', in: Renaissance Quarterly XXI, 1 (1968), 103-118. (b)

'La Mort et l'Office des Morts à l'époque du Maître de Boucicaut et les Limbourgs', in: Revue de l'Art (1968), 17-25. (c)

A Commemorative Gathering for Erwin Panofsky at the Institute of Fine Arts. New York University in Association with the Institute for Advanced Study, 21 March 1968

(New York: The Spiral Press, 1968), 8-10. (d)

with U. Procacci and U. Baldini (eds.), The Great Age of Fresco: From Giotto to Pontormo: An Exhibition of Mural Paintings and Monumental Drawings, exhibition catalogue (Florence: Il Fiorino, 1968). (e)

1969

'Florence and Venice Two Years Later', in: Renaissance Quarterly XXII, 1 (1969), 88-90.

1970

The Great Age of Fresco: Discoveries, Recoveries and Survivals (London: Phaidon, 1970). (a)

'Progress in Florence and Venice during 1969', in: Renaissance Quarterly XXIII, 1 (1970), 107-111. (b)

1971

The Master of the Breviary of Jean Sans Peur and the Limbourgs (London: Oxford University Press, 1971). (a)

La Sacra Conversazione di Piero della Francesca (Florence: Centro Di, 1971, Quaderni della Pinacoteca di Brera, I). (b)

'Alesso di Andrea', in: M. Salmi (ed.), Giotto e il suo tempo, conference proceedings, Assisi - Padua - Florence 24 September-1 October 1967 (Rome: De Luca, 1971), 401-418. (c)

with S. Off, 'The Bookkeeping of Robinet d'Estampes and the Chronology of Jean de Berry's Manuscripts', in: The Art Bulletin LIII, 2 (1971), 225-235. (d)

'Notable Disturbances in the Classification of Tuscan Trecento Painting', in: The Burlington Magazine CXIII, 817 (1971), 178-187. (e)

'Recovery in Florence and Venice during 1970', in: Renaissance Quarterly XXIV, 1 (1971), 121-123. (f) 
1972

'Bartolomeo Bulgarini', in: Dizionario biografico degli Italiani (Rome: Istituto della Enciclopedia Italiana, 1972), XV, 38-40. (a)

with S. Off, 'Deux miniatures perdues du Térence des Ducs', in: Revue de l'Art 15 (1972), 62-63. (b)

1973

'Ugo Procacci: Forty Years in the Florentine Soprintendenza', in: The Burlington Magazine CXV, 838 (1973), 41-42.

1974

French Painting in the Time of Jean de Berry: The Limbourgs and their Contemporaries, 2 vols. (New York: Braziller, 1974). (a)

'Raphael's Mechanized Seashell: Notes on a Myth, Technology and Iconographic Tradition', in: U.E. McCracken, L.M.C. Randall and R.H. Randall (eds.) Gatherings in Honor of Dorothy E. Miner (Baltimore MD: The Walters Art Gallery, 1974), 317332; republ. in: Meiss 1976, 203-211. (b)

'Scholarship and Penitence in the Early Renaissance: The Image of St. Jerome', in: Pantheon XXXII (1974), 134-140; republ. in: Meiss 1976, 189-202. (c)

1975

'Not an Ostrich Egg?', in: The Art Bulletin LVII, 1 (1975), 116.

1976

The Painter's Choice. Problems in the Interpretation of Renaissance Art (New York: Harper \& Row, 1976).

1982

Pittura a Firenze e Siena dopo la morte nera: arte, religione e società alla metà del Trecento (Turin: Einaudi, 1982).

1983

Francesco Traini, ed. by H.B.J. Maginnis (Washington DC: Decatur House Press, 1983).

1994

La peinture à Florence et à Sienne après la peste noire : les arts, la religion, la société au milieu du 14. siècle, ed. by G. Didi-Huberman (Paris: Hazan, 1994).

1997

'La "Sacra Conversazione" di Piero della Francesca', in: E. Daffra and F. Trevisani (eds.), La Pala di San Bernardino di Piero della Francesca. Nuovi studi oltre il restauro (Florence: Centro Di, 1997, Quaderni di Brera, 9), 11-22.

1998

Malerei in Florenz und Siena nach der grossen Pest: Kunst, Religion und Gesellschaft in der Mitte des vierzehnten Jahrhunderts (Dresden: Verlag der Kunst, 1998). 
$\because$ Taylor \& Francis Taylor \& Francis Group http://taylorandfrancis.com 


\section{Introduction}

Meiss was described as acute, confident, understated, introverted and tactful, but with a sense of humour. John Pope-Hennessy found in him that balance a good art historian needs, and was struck by how his personality corresponded exactly with his intellectual stature:

He could have astonished but refrained from doing so; he could have allowed a powerful imagination to draw him beyond the permissible limits of the evidence; he could have disturbed the careful balance between formulation and the thought that it expressed. But he did none of these things. ${ }^{1}$

Such a balance was also reflected in his approach, successfully combining the analysis of formal values, the knowledge of technical matters and the study of the meaning of works of art within their intellectual, historical and stylistic context. This multi-faceted and flexible modus operandi much owed to the complex and multi-layered nature of the discipline as it was in the 'Golden Age' of art history in the United States. ${ }^{2}$

Millard Lazare Meiss was born into a wealthy Jewish family in Cincinnati, Ohio, on 25 March 1904. In 1922 he attended the Princeton School of Architecture to train as an architect and earned a bachelor of arts in English and Literature in $1926 .{ }^{3} \mathrm{He}$ then started work as a construction supervisor at Schroeder and Koppel in New York, but not long afterwards realised art history was his true passion. Once he dispelled his father's qualms about studying history of art, Meiss was then able to resume his education. ${ }^{4}$ He chose Harvard instead of Princeton, probably because the New Jersey university was going through a period of economic strain following the death of Allan Marquand, its principal sponsor. This was, however, a thriving period for the teaching

1 Pope-Hennessy 1991, 305-306. Cf. also Glueck 1974 and Coolidge 1975.

2 This expression was famously used by Panofsky in his outline of the development of art history in the United States, 'Three Decades of Art History in the United States: Impressions of a Transplanted European', republished in Panofsky 1955, 321-346: 326. Cf. also DaCosta Kaufmann 2010.

3 On Princeton School of Architecture, see Aronberg Lavin 1983 and Van Zanten 1989.

4 'The Class of 1926' 1975: 'Upon graduation his father told him it was time for him to go to work. He did, in the construction industry, continuing his studies at night. He was construction supervisor on several New York buildings, and he recalled later that the experience of walking steel beams far above the ground conditioned him for later clambering in the upper reaches of Italian churches, studying frescoes up close. After two years, his father agreed to support his graduate study at Harvard and N.Y. University'. 


\section{Introduction}

of art history at Harvard. ${ }^{5}$ Paul J. Sachs was laying the foundations of a connoisseurship rooted in the scientific examination of techniques and materials and the study of art sources. ${ }^{6}$ Meiss later completed his post-graduate work under Richard Offner at the Institute of Fine Arts in New York, a mentor that honed his connoisseurial skills and initiated him to the study of Tuscan primitives. ${ }^{7}$ By then the New York institute had become a so-called 'university of exile', attracting the most prominent émigré scholars from Europe. Amongst them was Erwin Panofsky, who played a pivotal role in steering Meiss's interest towards Flemish painting and French illumination. But more importantly, Panofsky encouraged the younger art scholar to shift his attention to the content of artworks. In the course of a professional and personal lifelong relationship, Meiss, in turn, significantly contributed to the Americanisation of the iconological method put forward by 'Pan' - as his close friends called the German art historian. After he completed his doctorate, Meiss began his academic career as a lecturer - first at the Institute of Fine Arts in 1931-1933 and then at Columbia University from 1935 to 1937 . At Columbia, where his colleagues included the likes of Rensselaer W. Lee, Julius S. Held and Meyer Schapiro, Meiss became an assistant professor in 1937 and was made an associate professor in 1947. Between 1940 and 1942, he took on the prestigious editorship of The Art Bulletin, bringing a wind of change to the historic journal by broadening its scope to architecture, portraiture, contemporary art and Oriental and Latin American art. ${ }^{8}$ Discouraged by an art department he did not feel was lively enough, Meiss left New York in 1954 and went to teach at Harvard where he also served as curator of paintings in the Fogg Museum. Finally, in 1957 Meiss joined Panofsky at the Institute for Advanced Study in Princeton and ultimately succeeded him as chair of art history in 1962.

Meiss's name mainly became synonymous with the book Painting in Florence and Siena after the Black Death, whose contextual explanation of stylistic and iconographical changes in art was variously construed as either alternative or akin to the social history of art in the modes of Frederick Antal and Arnold Hauser. Another great scholarly achievement of his was the three-volume corpus, completed over the course of almost two decades, French Painting in the Time of Jean de Berry, which analysed French illumination as a crucible for cross-cultural fertilisation between Flemish and Italian artistic civilisations. Most of his body of work otherwise consisted of articles and short essays, thus choosing a form that lent itself to pursuing several threads of research and constantly re-elaborating topics. True to the Offnerian legacy, on the

5 Brush 2003, 200: 'The other Princeton scholars of the 1920s and 1930s, among them Morey, Ernest DeWald, E. Baldwin Smith, Frank Jewett Mather, Jr. and A.M. Friend, Jr., were not wealthy and did not move in the same circles as their Harvard counterparts; moreover, they did not travel so extensively in Europe during the 1920s. There was clear financial need at Princeton in the years following 1924. [...] As a result, the Princeton department, which has a small art museum and shared quarters with the School of Architecture for much of the 1920s, made do with an additive approach to its physical quarters during the 1920 s and 1930 s that did not express a single coherent vision'.

6 Meiss would indeed attend Sachs's famous Museum Course which trained generations of art scholars and museum professionals. On the Museum Course, refer to the recent Duncan and McClellan 2018.

7 Under Offner's supervision, Meiss ventured into the examination of the corpus of such artists as Ugolino Lorenzetti (active ca. 1320-1360) and Francesco Traini (active ca. 1321-1365); see Meiss 1931 and Meiss 1933.

8 Meiss 1964d. Also see Brilliant 1991; Lang 2013; Publishing the Art Bulletin: Past, Present and Future (http://scalar.usc.edu/anvc/the-art-bulletin/index). 
one hand, Meiss threw his hat into the ring with such prickly matters as the attributive quarrel over the Frick Flagellation debated between Cimabue and Duccio (Figure 1.6), and the even more heated problem of Giotto's presence in Assisi. His numerous lectures devoted to the 'neat unravelling of iconographic niceties', like the meaning of the ostrich egg in Piero della Francesca's Brera Altarpiece or of slumbering damsels in Venetian painting, concurrently testify to a Panofskyan course of research. ${ }^{9}$ These two differing approaches were successfully combined in the study of stylistic trends as embedded in a specific culture, which constituted the main purpose of Meiss's investigations.

Parallel to his scholarly output, Meiss was intent upon preserving artistic heritage and chaired the American committees that helped repair damaged works of art, both after the war and again after the 1966 flood in Florence. The American art historian was also an active member of Comité International d'Histoire de l'Art in the post-war years. In 1961 he brought to the United States its first international art congress, held in New York, and served as the organisation's president until 1964 and as a member of the executive bureau in the following years. The work alongside conservators and restorers further deepened Meiss's knowledge of the technical study of art, particularly as regards frescoes. The examination of the techniques used in mural painting became an engrossing pursuit for Meiss between the sixties and seventies, which resulted in his collaboration with Ugo Procacci and Leonetto Tintori. Dividing his time between conservation work in Florence, his academic engagements in Princeton as well as his institutional role within CIHA, Meiss would often have to defer his research, as was the case with the monumental corpus of French painting, which he began in the 1950s but was able to publish only at the end of the following decade. He retired from Princeton in 1973 and shortly thereafter was diagnosed with lung cancer.

Meiss played the violin; he was fluent in Italian and French, was well-versed in German and spoke a bit of Spanish, too. In his formative years, he spent extensive periods in Italy, Germany and France, and made shorter visits to England, Belgium and Holland. When his hopes to recover from cancer were disappointed, he travelled to Italy one last time and saw the places of what he considered to be his spiritual homeland - Florence, Siena and Venice. Not without strain, he managed to deliver two final lectures in Paris at the Collège de France on his beloved Très Riches Heures $d u$ Duc du Berry in the presence of a dear friend, André Chastel. Sadly, soon after, his condition grew worse and he died in Princeton on 12 June 1975. 


\section{Introduction}

\section{Bibliography}

Aronberg Lavin, M. (ed.), The Eye of the Tiger. The Foundation and Development of the Department of Art and Archaeology, 1883-1923, Princeton University, exhibition catalogue (Princeton NJ: The Art Museum, 1983).

Brilliant, R., 'The Squeaking Wheel, or The Art Bulletin at Seventy-Eight', in: The Art Bulletin LXXIII, 3 (1991), 358.

Brush, K., Vastly More than Brick and Mortar. Reinventing the Fogg Art Museum in the 1920s (Harvard MA: Harvard Art Museums, 2003).

Coolidge, J., 'Millard Meiss, Former Fogg Curator of Paintings', in: Fogg Art Museum Newsletter XIII, 1 (1975), 4.

DaCosta Kaufmann, T., 'American Voices. Remarks on the Earlier History of Art History in the United States and the Reception of Germanic Art Historians', in: Journal of Art Historiography 2 (2010), http://arthistoriography.files.wordpress.com/2011/02/media_152 488_en.pdf.

Duncan, S.A. and McClellan, A. (eds.), The Art of Curating: Paul J. Sachs and the Museum Course at Harvard (Los Angeles CA: Getty Research Institute, 2018).

Gilbert, C., 'Millard Meiss. Andrea Mantegna as Illuminator', in: College Art Journal XVII, 4 (1958), 434-436.

Glueck, G., 'Art History Colleagues Honor Millard Meiss', in: The New York Times (15 April 1974), 38.

Lang, K., 'The Art Bulletin at One Hundred', in: The Art Bulletin XCV, 1 (2013), 7.

Panofsky, E., Meaning in the Visual Arts. Papers in and on Art History (Princeton NJ: Princeton University Press, 1955).

Pope-Hennessy, J., Learning to Look (London: Heinemann, 1991).

The Class of 1926, 'Dr. Millard Meiss '26', in: Princeton Alumni Weekly (6 October 1975), 20.

Van Zanten, D., "'The Princeton System" and the Founding of the School of Architecture, 1915-1921', in: C.C. Mead (ed.), The Architecture of Robert Venturi (Albuquerque NM: University of New Mexico Press, 1989), 34-44. 


\section{Bibliography}

Glueck, G., 'Art History Colleagues Honor Millard Meiss', in: The New York Times (15 April 1974), 38.

Lavin, I., 'The Crisis of “Art History”', in: The Art Bulletin LXXVIII, 1 (1996), 13-15.

Rosand, D., 'Studies in Late Medieval and Renaissance Painting in Honor of Millard Meiss by Irving Lavin; John Plummer', in: Renaissance Quarterly XXXIII, 3 (1980), 446-448.

Aronberg Lavin, M. (ed.), The Eye of the Tiger. The Foundation and Development of the Department of Art and Archaeology, 1883-1923, Princeton University, exhibition catalogue (Princeton NJ: The Art Museum, 1983).

Brilliant, R., 'The Squeaking Wheel, or The Art Bulletin at Seventy-Eight', in: The Art Bulletin LXXIII, 3 (1991), 358.

Brush, K., Vastly More than Brick and Mortar. Reinventing the Fogg Art Museum in the 1920s (Harvard MA: Harvard Art Museums, 2003).

Coolidge, J., 'Millard Meiss, Former Fogg Curator of Paintings', in: Fogg Art Museum Newsletter XIII, 1 (1975), 4.

DaCosta Kaufmann, T., 'American Voices. Remarks on the Earlier History of Art History in the United States and the Reception of Germanic Art Historians', in: Journal of Art Historiography 2 (2010), http://arthistoriography.files.wordpress.com/2011/02/media_152 488_en.pdf.

Duncan, S.A. and McClellan, A. (eds.), The Art of Curating: Paul J. Sachs and the Museum Course at Harvard (Los Angeles CA: Getty Research Institute, 2018).

Gilbert, C., 'Millard Meiss. Andrea Mantegna as Illuminator', in: College Art Journal XVII, 4 (1958), 434-436.

Glueck, G., 'Art History Colleagues Honor Millard Meiss', in: The New York Times (15 April 1974), 38.

Lang, K., 'The Art Bulletin at One Hundred', in: The Art Bulletin XCV, 1 (2013), 7.

Panofsky, E., Meaning in the Visual Arts. Papers in and on Art History (Princeton NJ: Princeton University Press, 1955).

Pope-Hennessy, J., Learning to Look (London: Heinemann, 1991).

The Class of 1926, 'Dr. Millard Meiss '26', in: Princeton Alumni Weekly (6 October 1975), 20.

Van Zanten, D., "“The Princeton System” and the Founding of the School of Architecture, 1915-1921', in: C.C. Mead (ed.), The Architecture of Robert Venturi (Albuquerque NM: University of New Mexico Press, 1989), 34-44.

Ackerman, J.S. and Carpenter, R. (eds.), Art and Archaeology (Englewood Cliffs NY: Prentice Hall, 1963).

Ambrosini Massari, A., Bacchi, A., Benati, D. and Galli, A. (eds.), Il mestiere del conoscitore: Roberto Longhi (Bologna: Fondazione Federico Zeri, 2017).

Andaloro, M. and Cordaro, M. (eds.), Per Cesare Brandi, seminar proceedings, Rome 30-31 May 1984 (Rome: De Luca, 1988).

Arcangeli, F., 'Affreschi veronesi di Jacopino di Francesco', in: Paragone I, 9 (1950), 35-42.

Ars XLIV 1 (2011) [monographic issue on Max Dvořák].

Aurenhammer, H.H., 'Max Dvořák (1874-1921)', in: U. Pfisterer (ed.), Klassiker der Kunstgeschichte, 2 vols. (Munich: Beck, 2007-2008), I, 214-226.

Aurenhammer, H.H., 'Max Dvořák and the History of Medieval Art', in: Journal of Art Historiography 2 (2010), http://arthistoriography.files.wordpress.com/2011/02/media_152 487_en.pdf.

Baccheschi, E., L'opera completa di Duccio (Milan: Rizzoli, 1972).

Bagnoli, A., Bartalini, R., Bellosi, L. et al. (eds.), Duccio. Alle origini della pittura senese, exhibition catalogue, Siena 2003-2004 (Cinisello Balsamo: Silvana Editoriale, 2003).

Bakoš, J., 'Max Dvořák - A Neglected Re-Visionist', in: M. Theisen (ed.), Wiener Schule: Erinnerung und Perspektiven (Vienna- Cologne -Weimar: Böhlau, 2005), 55-71.

Bartalini, R., 'Luciano Bellosi (1936-2011)', in: Prospettiva 139-140 (2010-2012), 2-3. 


\section{Bibliography}

Bartalini, R., 'Postfazione', in: L. Bellosi (ed.), La pecora di Giotto (Milan: Abscondita, 2015), 357-382.

Bastek, A. and Müller, A. von (eds.), Kunst, Küche und Kalkül. Carl Friedrich von Rumohr (1785-1843) und die Entdeckung der Kulturgeschichte, exhibition catalogue (Petersberg: Imhof, 2010).

Battezzati, C., 'Carl Friedrich von Rumohr e l'arte nell'Italia settentrionale', in: Concorso 3 (2009), 6-23.

Battisti, E., Cimabue (Milan: Istituto Editoriale Italiano, 1963).

Battisti, E., Giotto (Geneva: Skira, 1960).

Bauch, K., 'Die geschichtliche Bedeutung von Giottos Frühstil', in: Mitteilungen des Kunsthistorischen Institutes in Florenz VII, 1 (1953), 43-64.

Bellosi, L., 'Da Spinello Aretino a Lorenzo Monaco', in: Paragone XVI, 187 (1965), 18-43.

Bellosi, L., 'Roberto Longhi e l'arte del Trecento, in: G. Previtali (ed.), L'arte di scrivere sull'arte. Roberto Longhi nella cultura del nostro tempo (Rome: Editori Riuniti, 1982), 27-36; republ. in: id: "I vivi parean vivi". Scritti di storia dell'arte italiana del Duecento e del Trecento (Florence: Centro Di, 2006), 454-457.

Bellosi, L., 'La rappresentazione dello spazio', in: G. Previtali (ed.), Storia dell'arte italiana (Turin: Einaudi, 1983), IV, 6-39.

Bellosi, L., La pecora di Giotto (Turin: Einaudi, 1985).

Bellosi, L., 'Per un contesto cimabuesco senese: b) Rinaldo da Siena e Guido di Graziano', in: Prospettiva 62 (1991), 15-28.

Bellosi, L., Cimabue (Milan: Federico Motta, 1998).

Bellosi, L., 'Giotto e la Basilica Superiore di Assisi', in: A. Tartuferi (ed.), Giotto. Bilancio critico di sessant'anni di ricerche, exhibition catalogue (Florence: Giunti, 2000), 33-54.

Bellosi, L., 'The Function of the Rucellai Madonna in the Church of Santa Maria Novella', in: V.M. Schmidt (ed.), Italian Painting of the Duecento and Trecento, symposium proceedings, Florence 5-6 June-Washington 16 October 1998 (New Haven CT: Yale University Press, 2002), 147-159.

Bellosi, L., Buffalmacco e il Trionfo della Morte (Milan: Five Continents, 2003; 1st ed. Turin: Einaudi, 1974).

Bellosi, L., "I vivi parean vivi". Scritti di storia dell'arte italiana del Duecento e del Trecento (Florence: Centro Di, 2006).

Bellosi, L., 'Testimonianze su Carlo Volpe', in: Paragone LXII, 101-102 (2012), 14-20.

Berenson, B., The Florentine Painters of the Renaissance (New York: Putnam, 1896).

Berenson, B., 'Ugolino Lorenzetti', in: Art in America V, 6 (1917), 259-275; VI, 1 (1917), $25-52$.

Berenson, B., Italian Pictures of the Renaissance. A List of the Principal Artists and their Works with an Index of Places (Oxford: Clarendon Press, 1932).

Berenson, B., Italian Pictures of the Renaissance. A List of the Principal Artists and their Works with an Index of Places. Florentine School, 2 vols. (London: Phaidon, 1963).

Berenson, B. and Longhi, R., Lettere e scartafacci 1912-1957, ed. by C. Garboli (Milan: Adelphi, 1993).

Bernabò, M., 'Un episodio della demonizzazione dell'arte bizantina in Italia: la campagna contro Strzygowski, Toesca e Lionello Venturi sulla stampa fascista nel 1930', in: Byzantinische Zeitschrift XCIV, 1 (2001), 1-10.

Bernabò, M., Ossessioni bizantine e cultura artistica in Italia. Tra D’Annunzio, fascismo e dopoguerra (Naples: Liguori Editore, 2003).

Bernabò, M., 'Roma, Bisanzio, Castelseprio: aggiornamenti dai manoscritti greci miniati di Giobbe', in: A.C. Quintavalle (ed.), Medioevo: immagini e ideologie, Conference proceedings, Parma 23-27 September 2002 (Milan: Electa, 2005), 191-197. 
Bertelli, C., 'Castelseprio e Milano', in: Centro Italiano di Studi sull'Alto Medioevo (ed.), Bisanzio, Roma e l'Italia nell'Alto Medioevo (Spoleto: Centro Italiano di Studi sull'Alto Medioevo, 1988), 869-906.

Bertelli, G. and Bertelli, P., 'Pietro Toesca, cenni biografici', in: E. Parlato (ed.), Altro rinascimento. Il giovane Filippo Lippi e la Madonna di Tarquinia (Milan: Officina Libraria, 2017), 112-116.

Bettagno, A., 'Cavalcaselle a San Giorgio', in: Arte Veneta XXVII, 1973, 356-357.

Betthausen, P., 'Rintelen, Friedrich', in: P. Betthausen, P.H. Feist and C. Fork (eds.), Metzler Kunsthistoriker Lexikon: zweihundert Porträts deutschsprachiger Autoren aus vier Jahrhunderten (Stuttgart- Weimar: Metzler, 2007²), 348-349.

Bettini, S., 'Studi recenti sull'arte bizantina', in: La Critica d'Arte VII, II 28 (1949), 135-147.

Blower, J., 'Max Dvořák and Austrian Denkmalpflege at War', in: Journal of Art Historiography 1 (2009), http://arthistoriography.files.wordpress.com/2011/02/media_1 39127_en.pdf.

Bognetti, G.P., Chierici, G. and De Capitani D’Arzago, A. (eds.), Santa Maria di Castelseprio (Milan: Fondazione Treccani degli Alfieri per la storia di Milano, 1948).

Bologna, F., 'Roberto Longhi, Giudizio sul Duecento', in: Lo Spettatore Italiano II, 3 (1949), $50-52$.

Bologna, F., 'Ciò che resta di un capolavoro giovanile di Duccio (Nuovi studi sulla formazione del maestro)', in: Paragone XI, 125 (1960), 3-31.

Bologna, F., La pittura italiana delle origini (Rome: Editori Riuniti, 1962).

Bologna, F., 'The Crowning Disc of a Duecento 'Crucifixion' and Other Points Relevant to Duccio's Relationship to Cimabue', in: The Burlington Magazine CXXV, 963 (1983), 330-340.

Bortolotti, L., Cieri Via, C., Di Monte, M.G. and Di Monte, M. (eds.), Meyer Schapiro e i metodi della storia dell'arte, conference proceedings, Rome 22-24 February 2006 (Rome: Mimesis, 2010).

Boskovits, M., 'Nuovi studi su Giotto e Assisi’, in: Paragone XXII, 261 (1971), 34-56.

Boskovits, M., 'Cenni di Pepo', in: Dizionario Biografico degli Italiani (Rome: Treccani, 1979), XXIII, 541-542.

Boskovits, M., 'Entry no 81', in: M. Medica (ed.), Duecento. Forme e colori del Medioevo a Bologna, exhibition catalogue (Venice: Marsilio, 2000), 277.

Boskovits, M., 'Da Duccio a Simone Martini', in: A.C. Quintavalle (ed.), Medioevo: la Chiesa e il Palazzo, Conference proceedings, Parma 20-24 September 2005 (Milan: Electa, 2007), 565-582.

Boskovits, M., 'Per Luciano Bellosi', in: I. Droandi (ed.), "In nome di buon pittore”: Spinello e il suo tempo, conference proceedings, Arezzo 8 November 2011 (Florence: Edifir, 2016), 27-44.

Brandi, C., 'Giotto', in: Le Arti I, 1 (1938), 5-21; 2 (1939), 116-131.

Brandi, C., Duccio (Florence: Vallecchi Editore, 1951).

Brown, D.A., 'Entry', in: M. Boskovits and D.A. Brown (eds.), Italian Paintings of the Fifteenth Century (New York - Oxford: Oxford University Press, 2003), 671-674.

Bucci, M., 'Un San Michele Arcangelo di Francesco Traini nel Museo Nazionale di Pisa', in: Paragone XIII, 147 (1962), 40-43.

Busuioceanu, A., 'Pietro Cavallini e la pittura romana del Duecento e del Trecento', in: Ephemeris Dacoromana III (1925), 259-406.

Caglioti, F., De Marchi, A. and Nova, A. (eds.), I conoscitori tedeschi tra Otto e Novecento (Milan: Officina Libraria, 2018).

Caleca, A., 'Per un profilo biografico di Carlo L. Ragghianti', in: M. Scotini (ed.), Carlo Ludovico Ragghianti e il carattere cinematografico della visione, exhibition catalogue (Milan: Charta, 2000), 52-66. 


\section{Bibliography}

Callegari, P. and Gabrielli, E. (eds.), Pietro Toesca e la fotografia: "saper vedere" (Milan: Skira, 2009).

Callmann, E., 'Thebaid Studies', in: Antichità Viva XIV, 3 (1975), 3-22.

Camille, M., "'How New York Stole the Idea of Romanesque Art": Medieval, Modern and Postmodern in Meyer Schapiro', in: Oxford Art Journal XVII, 1 (1994), 65-75.

Cannon, J., 'Luciano Bellosi, La pecora di Giotto', in: The Burlington Magazine CXXX, 1026 (1988), 701-702.

Carli, E., Duccio (Milan - Florence: Electa, 1952).

Carli, E., La pittura senese (Milan: Electa, 1955).

Carli, E., La pittura pisana del Trecento, 2 vols. (Milan: Martello, 1958-1961).

Carli, E., Capolavori del Museo di Pisa (Turin: Eri, 1961a).

Carli, E., Duccio di Buoninsegna (Milan: Aldo Martello, 1961b).

Carli, E., 'Recuperi e restauri senesi. I - Nella cerchia di Duccio', in: Bollettino d'Arte L, 1-2 (1965), 94-99.

Carrà, C., Giotto (Rome: Casa Editrice d'Arte Valori Plastici, 1924).

Castelnuovo, E., 'Mille vie della pittura italiana', in: id. (ed.), La pittura in Italia. Il Duecento e il Trecento (Milan: Electa, 1986), 7-24.

Cavazzini, L., 'Luciano Bellosi', in: A.C. Quintavalle (ed.), Medioevo, natura e figura, conference proceedings, Parma 20-25 September 2011 (Milan: Skira, 2015), 769-771.

Cecchi, E., Giotto (Milan: Hoepli, 1937).

Cecchi, E., Pietro Lorenzetti (Milan: Treves, 1930).

Chastel, A., 'Chronique de l'art ancien et moderne. Fin du Moyen Age et Renaissance', in: La Revue des Arts I, 4 (1951), 251-256.

Chiodo, S., 'Il Corpus of Florentine Painting da Richard Offner a Miklós Boskovits', in: Ars Hungarica XLI, 3 (2015), 301-308.

Cohen, R., Bernard Berenson: A Life in Picture Trade (New Haven CT: Yale University Press, 2013).

Cole, B., 'Richard Offner and Modern Trecento Scholarship', in: R. Offner, Studies in Florentine Painting. The Fourteenth Century (New York: Junius Press, $1972^{2}$ ), unpaged.

Coletti, L., Gli affreschi della Basilica di Assisi (Bergamo: Istituto Italiano d'Arti Grafiche, 1949).

Connors, J. (ed.), Bernard Berenson: Formation and Heritage (Cambridge MA: Harvard University Press, 2014).

Conti, A., 'John White, Duccio, Tuscan Art and the Medieval Workshop', in: Prospettiva 23 (1980), 98-101.

Contini, G., 'Sul metodo di Roberto Longhi', in: Belfagor IV, 2 (1949), 205-210.

Cooke, J., 'Nota', in: E. Panofsky, 'Imago Pietatis. Un contributo alla storia tipologica dell'Uomo dei dolori e della Maria Mediatrix (1927)', in: Annali di Critica d'Arte 10 (2015), 9-74.

Cooper, D. and Robson, J., The Making of Assisi : The Pope, the Franciscans and the Painting of the Basilica (New Haven CT: Yale University Press, 2013).

Crivello, F. (ed.), Pietro Toesca all'Università di Torino: a un secolo dall'istituzione della cattedra di Storia dell'arte medievale e moderna 1907-1908/2007-2008, symposium proceedings, Turin 17 October 2008 (Alessandria: Edizioni dell'Orso, 2011).

Croce, B., 'Roberto Longhi, Arte italiana ed arte tedesca', in: La Critica XL, 3 (1942), 161-162.

Crowe, J.A. and Cavalcaselle, G.B., A New History of Painting in Italy, 3 vols. (London: Murray, 1864).

Crowe, J.A. and Cavalcaselle, G.B., A History of Painting in Italy. Umbria Florence and Siena from the Second to the Sixteenth Century, vol. II Giotto and the Giottesque (London: Murray, 1923).

Cumming, R. (ed.), My dear BB. The Letters of Bernard Berenson and Kenneth Clark, 19251959 (New Haven CT - London: Yale University Press, 2015). 
Cutler, A., 'La questione bizantina nella pittura italiana: una visione alternativa della maniera greca', in: C. Bertelli (ed.), La pittura in Italia. L'Altomedioevo (Milan: Electa, 1994), 335-354.

Davidson, B.F., The Frick Collection. An Illustrated Catalogue, 8 vols. (New York: The Frick Collection, 1968).

De Benedictis, C., La pittura senese 1330-1370 (Florence: Salimbeni, 1979).

De Marchi, A., 'Luciano Bellosi (1936-2011)', in: Mitteilungen des Kunsthistorischen Instutes in Florenz LIV, 1 (2010-2012), 207-210.

De Marchi, A., “"Il bel colore gemmato su fondo d'oro”. La collezione di Riccardo Gualino fra il Castello di Cereseto e la casa di via Galliari, gli acquisti di "primitivi” prima e dopo Lionello Venturi', in: A. Bava and G. Bertolino (eds.), I mondi di Riccardo Gualino: collezionista e imprenditore, exhibition catalogue (Turin: Allemandi, 2019), 111-125.

De Spirito, G., 'A propos des peintures murales de l'église Santa Maria foris portas de Castelseprio', in: Cahiers archéologiques XLVI (1998), 23-64.

Deuchler, F., Duccio (Milan: Electa, 1984).

DeWald, E.T., 'The Master of the Ovile Madonna', in: Art Studies I (1923), 45-54.

Di Benedetto, A., 'Memoria di un'inimicizia: omaggio a Berenson e a Longhi', in: Intersezioni XVII 2 (1997), 315-323.

Dilk, E.Y., Das "verzweifelte allerhand Talent". Neue Studien zu Carl Friedrich von Rumohr (Hildesheim: Olms, 2010).

Donati, P.P., 'Il punto su Manfredino d'Alberto', in: Bollettino d'Arte LVII, 3-4 (1972), 149.

Dvořák, M., 'Das Rätsel der Kunst der Brüder van Eyck', in: Jahrbuch der Kunsthistorischen Sammlungen in Wien XXIV, 5 (1903), 161-319.

Fiocco, G., 'Rintelen (Friedrich): Giotto und die Giotto-Apokryphen', in: L'Arte XV 30, (1912), 397.

Fiocco, G., 'Gli appunti di Giambattista Cavalcaselle', in: Arte Veneta VI (1952), 208-210.

Fisher, M.R., 'Assisi, Padua, and the Boy in the Tree', in: The Art Bulletin XXXVIII, 1 (1956), 47-52.

Fisher, M.R., 'Millard Meiss, Giotto and Assisi', in: Renaissance News XIV, 4 (1961), 252-254.

Förster, E., Beiträge zur neuern Kunstgeschichte (Leipzig: Brockhaus, 1835).

Frick Symington Sanger, M., Helen Clay Frick: Bittersweet Heiress (Pittsburgh NY: University of Pittsburgh Press, 2008).

Gabrielli, E., 'Pietro Toesca: il riscatto del Medioevo italiano', in: A. Masi (ed.), L'occhio del critico: storia dell'arte in Italia tra Otto e Novecento (Florence: Vallecchi, 2009), 41-56.

Gabrielli, M., Giotto e l'origine del realismo (Rome: Bardi, 1960).

Galassi, C. (ed.), Critica d'arte e tutela in Italia: figure e protagonisti nel secondo dopoguerra, conference proceedings, Perugia 17-19 November 2015 (Perugia: Aguaplano, 2017).

Gardner, J. and Mahon, D., 'Cesare Gnudi', in: The Burlington Magazine CXXIII, 938 (1981), 304, 307.

Gardner, J., 'Obituary. Edward B. Garrison', in: The Burlington Magazine CXXIV, 947 (1982), 96-97.

Garrison, E.B., Italian Romanesque Panel Painting: An Illustrated Index (Florence: Olschki, 1949).

Garrison, E.B., 'The Role of Criticism in the Historiography of Painting', in: College Art Journal X, 2 (1951), 110-120.

Gibbs, R., 'Cimabue', in: J. Turner (ed.), The Grove's Dictionary of Art, 34 vols. (London: Macmillan, 1996), VII, 319.

Gioseffi, D., 'Lo svolgimento del linguaggio giottesco da Assisi a Padova: il soggiorno riminese e la componente ravennate', in: Arte Veneta XV (1961), 11-24.

Gioseffi, D., Giotto architetto (Milan: Edizioni di Comunità, 1963).

Gnudi, C., Giotto (Milan: Aldo Martello, 1958). 


\section{Bibliography}

Gnudi, C., 'Il passo di Riccobaldo Ferrarese relativo a Giotto e il problema della sua autenticità', in: P.A. Underwood (ed.), Studies in the History of Art Dedicated to William E. Suida on his Eightieth Birthday (London: Phaidon, 1959), 26-30.

Gordon, D., 'The Virgin and Child by Cimabue at the National Gallery', in: Apollo CLVII, 496 (2003), 32-36.

Gosebruch, M., 'Giovanni Previtali, Giotto e la sua bottega', in: Kunstchronik XX, 9 (1969), 262.

Grasman, E., 'Raimond van Marle (1887-1936): een kort leven in de kunst', in: Incontri XVI, 3-4 (2001), 167-179.

Harris, J., 'In Honour of Osvald Sirén, and Recollections', in: Apollo CXXXIV, 354 (1991), 104-107.

Heckscher, W.S., 'Erwin Panofsky: A Curriculum Vitae', in: Record of the Art Museum. Princeton University XXVIII, 1 (1969), 4-21.

Hemingway, A., 'Meyer Schapiro and Marxism in the 1930s', in: Oxford Art Journal XVII, 1 (1994), 13-29.

Hemingway, A., 'Meyer Schapiro: Marxism, Science and Art', in: id. (ed.), Marxism and the History of Art. From William Morris to the New Left (London: Pluto Press, 2006), 123-142.

Hermanin, F., 'Gli affreschi di Pietro Cavallini a Santa Cecilia in Trastevere', in: Le gallerie nazionali italiane V (1902), 61-115.

Hermanin, F., 'Il maestro romano di Giotto', in: Almanacco di Roma (1924), 148-161.

Honour, H., 'Introduction', in: O. Sirén, China and Gardens of Europe of the Eighteenth Century (Washington DC: Dumbarton Oaks, 1990), v-ix.

Hope, H.R., 'Richard Offner (1879-1965)', in: The Art Journal XXV, 1 (1965), 54.

Hoving, T.P.F., 'The Berenson Scandals. An Interview with Colin Simpson', in: Connoisseur CCXVI, 897 (1986), 132-137.

Hutton, E., Assisi and Umbria Revisited (London: Hollis and Carter, 1953).

Hutton, E., 'F. Mason Perkins', in: The Burlington Magazine XCVII, 633 (1955), 391-392.

Iselt, K., 'Robert Oertel (1907-1981) - Kustos der Gemäldegalerie Dresden 1939-1946', in: Dresdener Kunstblätter LVI, 1 (2012), 45-54.

Isermeyer, C.A., 'Robert Oertel, 1907-1981', in: Zeitschrift für Kunstgeschichte XLV, 4 (1982), 437-440.

Journal of Aesthetics and Art Criticism LV, 1 (1997) [monographic issue on Meyer Schapiro].

Kleinbauer, W.E. and Slavens, T.P. (eds.), Research Guide to the History of Western Art (Chicago IL: American Library Association, 1982).

Laclotte, M., Histoires des musées. Souvenirs d'un conservateur (Paris: Editions Scala, 2003).

Laclotte, M., 'Luciano Bellosi (1935-2011)', in: Revue de l'Art 174 (2011), 109.

Ladis, A. (ed.), A Discerning Eye. Essays on Early Italian Painting by Richard Offner (University Park PA: The Pennsylvania State University Press, 1998).

Lavagnino, E., Storia dell'arte medievale italiana (Turin: UTET, 1936).

Levi, D., Cavalcaselle. Il pioniere della conservazione dell'arte italiana (Turin: Einaudi, 1988).

Lochoff, L., 'Gli affreschi dell'antico e del nuovo testamento nella basilica superiore di Assisi', in: Rivista d'Arte II, IX, 3-4 (1937), 240-270.

Longhi, R., 'Me Pinxit', in: Pinacotheca I, 2 (1928), 74.

Longhi, R., 'Vitale da Bologna e i suoi affreschi nel Camposanto di Pisa (1931)', in: Mitteilungen des kunsthistorischen Institutes in Florenz IV (1932-1934), 135-137; republ. in: Paragone I 5 (1950), 32-35 and published in full in: id., Lavori in Valpadana (Florence: Sansoni, 1973), 207-226.

Longhi, R., La pittura padana del Trecento (Bologna: Università, 1935); republ. in: id., Lavori in Valpadana cit., 3-90.

Longhi, R., 'Giudizio sul Duecento', in: Proporzioni II (1948), 5-54; republ. in: id., Giudizio sul Duecento e ricerche sul Trecento nell'Italia centrale (Florence: Sansoni, 1974), 1-53. 
Longhi, R., 'Mostra della pittura bolognese del Trecento', in: Paragone I, 5 (1950), 5-44; republ. in: id., Lavori in Valpadana cit., 155-169.

Longhi, R., 'Prima Cimabue, poi Duccio', in: Paragone II, 23 (1951), 8-13.

Longhi, R., 'Omaggio a Benedetto Croce', in: Paragone III, 35 (1952), 5.

Longhi, R., 'Un dossale a St. Jean-Cap-Ferrat', in: Paragone XII, 141 (1961), 11-19.

Longhi, R., 'Qualche altro appunto sul Traini e suo seguito', in: Paragone XIII, 147 (1962), 43-45.

Louchheim, A.B., 'Rare Art Acquired by the Frick Museum', in: The New York Times (1 February 1951a), 27.

Louchheim, A.B., 'Splendid Trinity for the Frick', in: ArtNews XLIX, 10 (1951b), 20-22.

Maginnis, H.B.J., 'Assisi Revisited: Notes on Recent Observations', in: The Burlington Magazine CXVII, 869 (1975), 511-517.

Maginnis, H.B.J., 'Luciano Bellosi, Buffalmacco e il Trionfo della Morte', in: The Art Bulletin LVIII, 1 (1976), 126-128.

Maginnis, H.B.J., 'The Role of Perceptual Learning in Connoisseurship: Morelli, Berenson, and Beyond', in: Art History XIII, 1 (1990), 104-117.

Maginnis, H.B.J., Painting in the Age of Giotto. A Historical Reevaluation (University Park PA: Pennsylvania University Press, 1997).

Maginnis, H.B.J., 'In Search of an Artist', in: A. Derbes and M. Sandona (eds.), The Cambridge Companion to Giotto, (Cambridge: Cambridge University Press, 2004), 10-31.

Marangoni, M., 'La Crocifissione del Camposanto di Pisa', in: L'Arte XXXIV, II 1 (1931), 3-29.

Markója, C., 'János (Johannes) Wilde and Max Dvořák, or Can we speak of a Budapest school of art history?' in: Journal of Art Historiography 17 (2017), https://arthistoriography.word press.com/17-dec $17 /$.

Marle, R. van, Recherches sur l'iconographie de Giotto et de Duccio (Strasbourg: J.H.Ed. Heitz, 1920).

Marle, R. van, 'La scuola del Cavallini a Rimini', in: Bollettino d'Arte I, 1 (1921), 248-261.

Mascolo, M.M., "'Una spuntatura affrettata”: Arte italiana e arte tedesca di Roberto Longhi', in: Prospettiva 155-156 (2014), 151-166.

Mather Jr., F.J., The Isaac Master. A Reconstruction of the Work of Gaddo Gaddi (Princeton NJ: Princeton University Press, 1932).

Mather Jr., F.J., 'Giotto's St. Francis Series at Assisi Historically Considered', in: The Art Bulletin XXV, 2 (1943), 97-111.

Middeldorf, U., 'Richard Offner in memoriam magistri et amici', in: Kunstchronik XIX (1966), 21-23.

Monciatti, A., Alle origini dell'arte nostra. La Mostra giottesca del 1937 a Firenze (Milan: Il Saggiatore, 2010).

Moretti, L. (ed.), G.B. Cavalcaselle: disegni da antichi maestri, exhibition catalogue (Vicenza: Neri Pozza, 1973).

Morey, C.R., 'Art and the History of Art in Italy', in: College Art Journal X, 3 (1951), 219-222.

Nicholson, A., 'Again the St. Francis Series', in: The Art Bulletin XXVI, 3 (1944), 193-196.

Nicolai, F., 'More Than an Expatriate Scholar: Frederick Mason Perkins as art adviser, agent and intermediary for American collectors of the twentieth century', in: Journal of the history of collections XXVIII, 2 (2016), 311-325.

Noszlopy, G.T., 'Millard Meiss, Giotto and Assisi', in: Art Journal XXVIII, 1 (1968), 120, 122.

Oertel, R., 'Wende der Giotto-Forschung', in: Zeitschrift für Kunstgeschichte XI, 1-2 (19431944), 1-27.

Oertel, R., Early Italian Painting to 1400 (London: Thames and Hudson, 1968); or. ed. id., Die Frühzeit der italienischen Malerei (Stuttgart: W. Kohlhammer, 1953).

Offner, R., 'Italian Pictures at the New York Historical Society and Elsewhere, II', in: Art in America VII, 5 (1919), 189-198.

Offner, R., 'A Remarkable Exhibition of Italian Paintings', in: The Arts V, 5 (1924), 241-264. 


\section{Bibliography}

Offner, R., Italian Primitives at Yale University (New Haven CT: Yale University Press, 1927a).

Offner, R., Studies in Florentine Painting. The Fourteenth Century (New York: Junius Press, 1927b).

Offner, R., 'Four Panels, a Fresco and a Problem', in: The Burlington Magazine LIV, 314 (1929), 224-245.

Offner, R. (ed.), A critical and Historical Corpus of Florentine Painting, 14 vols. (New York: Institute of Fine Arts, 1930-1981).

Offner, R., 'Giotto, Non-Giotto', in: The Burlington Magazine LXXIV, 435 (1939), 259-268; LXXV, 438 (1939), 96-113; republ. in: Ladis 1998, 61-88.

Offner, R., 'Guido da Siena and A.D. 1221', in: Gazette des Beaux-Arts XXXVIII (1950), 61-90.

Offner, R., 'Connoisseurship', in: ArtNews L, 1 (1951), 24-25, 62-63.

Offner, R., 'Preface', in: G. Kaftal, Iconography of the Saints in Tuscan Painting (Florence: Sansoni, 1952), xi-xiii.

Offner, R., 'Restoration and Conservation', in: Meiss IV (1963), 152-162.

Pace, V., 'La questione bizantina in alcuni monumenti dell'Italia altomedievale: la "perizia greca" nei "tempietti" di Cividale e del Clitumno, Santa Maria foris portas a Castelseprio e San Salvatore a Brescia, Santa Maria Antiqua a Roma', in: A.C. Quintavalle (ed.), Medioevo mediterraneo: l'Occidente, Bisanzio e l'Islam, conference proceedings, Parma 21-25 September 2004 (Milan: Electa, 2007), 215-223.

Panofksy, E., 'Imago Pietatis', in: Festschrift für Max J. Friedländer zum 60. Geburtstage (Leipzig: Seeman, 1927), 261-308.

Panofsky, E., Renaissance and Renascences in Western Art (Stockholm: Almqvist \& Wiksell/ Gebers Förlag AB, 1960).

Papenbrock, M., 'Kurt Bauch in Freiburg 1933-1945', in: Kunst und Politik V (2003), 195-215.

Passini, M., 'Arte italiana e arte tedesca nell'opera di Henry Thode', in: S. Frommel and A. Brucculeri (eds.), L'idée du style dans l'historiographie artistique: variantes nationales et transmissions (Rome: Campisano, 2013), 273-283.

Perkins, F.F.M., 'Letter. Giotto and Assisi', in: The Burlington Magazine LXXV, 437 (1939), 85.

Pesenti, F.R., 'Maestri arnolfiani di Assisi', in: Studi di storia delle arti (1977), 43-53.

Petrioli, P.G., 'Da Lord Lindsay a Bernard Berenson. La pittura senese nella storia dell'arte anglosassone', in: M. Civai (ed.), Siena tra storia e mito nella cultura anglosassone (Siena: Betti Editrice, 1996), 38-51.

Polzer, J., 'Aristotle, Mohammed and Nicholas V in Hell', in: The Art Bulletin XLVI, 4 (1964), 457-469.

Polzer, J., 'Observations on known paintings and a new altarpiece by Francesco Traini', in: Pantheon XXIX 5 (1971), 379-389.

Polzer, J., 'The "Triumph of St Thomas" panel in Santa Caterina, Pisa. Meaning and date', in: Mitteilungen des Kunsthistorischen Institutes in Florenz XXXVII, 1 (1993), 29-70.

Polzer, J., 'Who is the Master of the Crucifixion in the Campo Santo of Pisa?', in: Studi di Storia dell'Arte 21 (2010), 9-40.

Polzer, J., 'Michelangelo's Sistine "Last Judgment" and Buffalmacco's Murals in the Campo Santo of Pisa', in: Artibus et Historiae XXV, 69 (2014), 53-77.

Pope-Hennessy, J., 'Proporzioni II', in: The Burlington Magazine CX, 549 (1948), 359-360.

Pope-Hennessy, J., 'Recent Research', in: The Burlington Magazine XCIV, 588 (1952), 82-87.

Pope-Hennessy, J., 'Mrs. Evelyn Sandberg-Vavala', in: The Burlington Magazine CIII, 704 (1961), 466-467.

Pope-Hennessy, J., 'A Misfit Master', in: New York Review of Books XXVII, 18 (1980), 45-47.

Pope-Hennessy, J., Learning to Look (London: Heinemann, 1991).

Previtali, G., 'Giotto and Assisi, di Millard Meiss', in: Paragone XIII, 147 (1962), 63-65.

Previtali, G., Gli affreschi di Giotto ad Assisi (Milan: Fabbri - Skira, 1965).

Previtali, G., Giotto e la sua bottega (Milan: Fabbri Editori, 1967).

Procacci, U., Sinopie e affreschi (Milan: Electa, 1961). 
Ragghianti, C.L., 'Come lavorava un critico nell'Ottocento', in: seleArte I, 2 (1952), 3-9.

Ragghianti, C.L., Pittura del Dugento a Firenze (Florence: Stabilimento Tipolitografico Vallecchi, 1955).

Rampley, M., 'Max Dvořák: Art History and the Crisis of Modernity', in: Art History XXVI, 2 (2003), 214-237.

Reist, I., 'Helen Clay Frick: Charting her own Course', in: ead. and R. Mamoli Zorzi (eds.), Power Underestimated: American Women Art Collectors (Venice: Marsilio, 2011), 161-183.

Rintelen, F., Giotto und die Giotto-Apokryphen (Munich - Leipzig: Georg Müller, 1912).

Robinon, D., 'Alastair Smart (1922-1992)', in: The Burlington Magazine CXXXV, 1084 (1993), 486.

Rolfi, S., 'Appunti dall'archivio di un funzionario delle Belle Arti: Federico Hermanin da Cavallini a Caravaggio', in: Bollettino d'Arte s. VI, LXXXV, 114 (2000), 1-28.

Romanini, A.M., 'Gli occhi di Isacco. Classicismo e curiosità scientifica tra Arnolfo di Cambio e Giotto', in: Arte medievale I, 1-2 (1987), 1-43.

Romanini, A.M., 'Arnolfo all'origine di Giotto: l'enigma del Maestro di Isacco', in: Storia dell'arte 65 (1989), 5-26.

Rowland, B. Jr., 'Review of Painting in Florence and Siena after the Black Death, Millard Meiss', in: The Art Bulletin XXXIV, 4 (1952), 319-322.

Rumohr, C.F. von, Italienische Forschungen, ed. by J. von Schlosser (Frankfurt am Main: Frankfurters Verlags Anstalt, 1920²).

Salmi, M., 'Per la storia della Pittura a Pistoia ed a Pisa', in: Rivista d'Arte XIII, 4 (1931), 451-476.

Salmi, M., 'Le origini dell'arte di Giotto', in: Rivista d'Arte XIX (1937), 193-220.

Salmi, M. (ed.), Giotto e il suo tempo, conference proceedings, Assisi - Padua - Florence 24 September - 1 October 1967 (Rome: De Luca, 1971).

Salvini, R., 'Apologia di Bisanzio', in: Rassegna d'Italia III, 11 (1948), 1132-1141; republ. in: id., Medioevo nordico e Medioevo mediterraneo. Raccolta di scritti (1934-1985) (Florence: Studio Per Edizioni Scelte, 1987), 289-298.

Salvini, R., Tutta la pittura di Giotto (Milan: Rizzoli, 1952).

Salvini, R., Tutta la pittura di Giotto (Milan: Rizzoli, 1962²).

Samuels, E., Bernard Berenson: The Making of a Legend (Cambridge MA: The Belknap Press of Harvard University Press, 1987).

Sandberg-Vavalà, E., La croce dipinta italiana e l'iconografia della Passione (Verona: Casa Editrice Apollo, 1929).

Sandberg-Vavalà, E., L'iconografia della Madonna col Bambino nella pittura italiana del Dugento (Siena: Stabilimento d'arti grafiche San Bernardino, 1934).

Sandberg-Vavalà, E., Sienese Studies. The Development of the School of Painting of Siena (Florence: Olschki, 1953).

Sauerländer, W., 'Kurt Bauch', in: Kunstchronik XXVIII (1975), 375-379.

Sauerländer, W., 'The Great Outsider: Meyer Schapiro', in: id. (ed.), Romanesque Art: Problems and Monuments, 2 vols. (London: Pindar Press, 2004), II, 833-849.

Scarpellini, P., 'Henry Thode, Francesco d'Assisi e le origini dell'arte del Rinascimento in Italia', in: Commentari d'Arte I, 1 (1995), 69-72.

Scarrocchia, S., Max Dvořák: conservazione e moderno in Austria (1905-1921) (Milan: Franco Angeli, 2009).

Schapiro, M., 'On an Italian Painting of the Flagellation of Christ in the Frick Collection', in: M. Salmi (ed.), Scritti di storia dell'arte in onore di Lionello Venturi, 2 vols. (Rome: De Luca, 1956), I, 29-53.

Schlosser, J. von, 'Poesia e arte figurative nel Trecento', in: Critica d'Arte III, 3 (1938), 81-90.

Schöne, W., 'Studien zur Oberkirche von Assisi', in: B. Hackelsberger, G. Himmelheber and M. Meier (eds.), Festschrift Kurt Bauch. Kunstgeschichtliche Beiträge zum 25. November 1957 (Berlin: Deutscher Kunstverlag, 1957), 50-116. 


\section{Bibliography}

Secrest, M., Duveen: A Life in Art (New York: Knopf, 2004).

Seidel, L., “'Shalom Yehudin!” Meyer Schapiro's Early Years in Art History', in: The Journal of Medieval and Early Modern Studies 27 (1997), 559-594.

Simpson, C., 'The Bilking of Jules Bache', in: Connoisseur CCXVI, 897 (1986), 126-131.

Simpson, C., The Partnership. The Secret Association of Bernard Berenson and Joseph Duveen (London: The Bodley Head, 1987).

Sindona, E., L'opera completa di Cimabue e il momento figurativo pregiottesco (Milan: Rizzoli, 1975).

Sinibaldi, G. and Brunetti, G. (eds.), Pittura italiana del Duecento e Trecento, exhibition catalogue (Florence: Sansoni, 1943).

Sirén, O., Giotto and Some of His Followers, 2 vols. (Cambridge MA: Harvard University Press, 1917).

Smart, A., 'The St. Cecilia Master and his School at Assisi I-II', in: The Burlington Magazine CII, 690 (1960a), 404-413; 691, 1960, 430-439.

Smart, A., 'Giotto and Assisi', in: The Burlington Magazine CII, 693 (1960b), 240-241.

Smart, A., The Assisi Problem and the Art of Giotto. A Study of the Legend of St. Francis in the Upper Church of San Francesco, Assisi (Oxford: Clarendon Press, 1971).

Smyth, C.H., 'Foreword', in: H.B.J. Maginnis (ed.), The Fourteenth Century. A Legacy of Attributions (Florence: Giunti, 1981), ix-xii.

Smyth, C.H. and Lukehart, P.M. (eds.), The Early Years of Art History in the United States. Notes and essays on Departments, Teaching, and Scholars (Princeton NJ: Princeton University Press, 1993).

Steinhoff, J.B., Bartolomeo Bulgarini and Sienese painting of the Mid-Fourteenth Century, 2 vols. (Princeton NJ: Princeton University, Phil. Diss., 1990).

Steinhoff, J.B., Sienese Painting After the Black Death. Artistic Pluralism, Politics and the New Art Market (Cambridge: Cambridge University Press, 2007).

Stirneman, P.D., 'Meyer Schapiro as Iconographer', in: C. Hourihane (ed.), The Routledge Companion to Medieval Iconography (London - New York: Routledge, 2017), 142-153.

Stirton, P., 'Frederick Antal', in: A. Hemingway (ed.), Marxism and the History of Art. From William Morris to the New Left (London: Pluto Press, 2006), 45-66, 231-237.

Stoichita, V.I., Ucenicia lui Duccio di Buoninsegna. Studii despre cultura figurativă a secolului al XIII-lea (Bucharest: Editura Meridiane, 1976).

Strehlke, C.B., 'Luciano Bellosi (1936-2011)', in: The Burlington Magazine CLIII, 1300 (2011), 479-480.

Stubblebine, J.H., An Altarpiece by Guido da Siena and His Narrative Style, dissertation (New York: New York University, 1958).

Stubblebine, J.H., Guido da Siena (Princeton NJ: Princeton University Press, 1964).

Stubblebine, J.H., 'The Frick Flagellation Reconsidered', in: Gesta XI (1972), 3-10.

Stubblebine, J.H., Duccio di Buoninsegna and his School, 2 vols. (Princeton NJ: Princeton University Press, 1979).

Supino, I.B., 'Il Trionfo della Morte e il Giudizio Universale nel Camposanto di Pisa', in: Archivio Storico dell'Arte VII, 1 (1894), 21-40.

Supino, I.B., Il Camposanto di Pisa (Florence: Fratelli Alinari Editori, 1896).

Swarzenski, H., 'Before and After Pisano', in: Boston Museum Bulletin LXVIII (1970), 178-196.

Szylin, A.M., Henry Thode (1857-1920). Leben und Werk (Frankfurt am Main: Lang, 1993).

Thode, H., Francesco d'Assisi e le origini dell'arte del Rinascimento in Italia (Rome: Donzelli, 1993); or. ed. id., Franz von Assisi und die Anfänge der Kunst der Renaissance in Italien (Berlin: Grote, 1885).

Thomas, K., “The art historian among artists": Kunstkritik und Kunstgeschichte bei Meyer Schapiro', in: Zeitschrift für Kunstgeschichte LXXVIII, 1 (2015), 45-64.

Toesca, P., Giotto (Turin: UTET, 1941).

Toesca, P., ‘Gioventù di Giotto', in: Civiltà III, 8 (1942), 29-50. 
Toesca, P., Il Trecento (Turin: UTET, 1951).

Toesca, P., 'Una postilla alla "Vita di San Francesco" nella chiesa superiore di Assisi', in: P.A. Underwood (ed.), Studies in the History of Art Dedicated to William E. Suida on his Eightieth Birthday (London: Phaidon, 1959), 21-25.

Tomei, A., 'Giotto', in: A.M. Romanini (ed.), Enciclopedia di Storia dell'Arte Medievale, 12 vols. (Rome: Istituto della Enciclopedia Italiana Treccani, 1991-2002), VI (1995), 656.

Tomei, A., 'La decorazione della Basilica di San Francesco ad Assisi come metafora della questione giottesca', in: id. (ed.), Giotto e il Trecento. "Il più Sovrano Maestro stato in dipintura», exhibition catalogue (Geneva - Milan: Skira, 2009), 31-49.

Tommasi, A.C. (ed.), Giovanni Battista Cavalcaselle conoscitore e conservatore, conference proceedings, Legnago 28 November 1997-Verona, 29 November 1997 (Venice: Marsilio, 1998).

Toscano, B., 'Restauri e mutamento disciplinare della storia dell'arte', in: C. Piva and I. Sgarbozza (eds.), Il corpo dello stile. Cultura e lettura del restauro nelle esperienze contemporanee. Studi in ricordo di Michele Cordaro, conference proceedings, Rome 20-21 February 2004 (Rome: De Luca, 2005), 40-41.

Trotta, A., Rinascimento americano. Bernard Berenson e la collezione Gardner 1894-1924 (Naples: La Città del Sole, 2003).

Tümpel, C., 'In memoriam Wolfgang Schöne. Predigt zu seiner Beedigung, Timmerdorfer Strand am 28. August 1989', in: Idea IX (1990), 7-12.

Urbini, S., 'Henry Thode fra storia, arte e romanzo: l'anello dei Frangipane', in: U. Rozzo and M. Gabriele (eds.), Storia per parole e per immagini (Udine: Forum, 2006), 319-346.

Urbini, S., Somnii explanatio. Novelle sull'arte italiana di Henry Thode (Rome: Viella, 2014).

Vakkari, J., 'Alcuni contemporanei finlandesi di Lionello Venturi: Osvald Sirén, Tancred Borenius, Onni Okkonen', in: Storia dell'Arte 101 (2002), 109-110.

Van Os, H.W., 'Duccio', in: The Burlington Magazine CXXIII, 936 (1981), 165-167.

Venturi, A., 'I. Benvenuto Supino: Arte Pisana', in: L'Arte VII, 13 (1904), 204-206.

Vigni, G., Pittura del Due e Trecento nel Museo di Pisa (Palermo: Palumbo, 1950).

Volpe, C., 'Preistoria di Duccio', in: Paragone V, 49 (1954), 4-22.

Volpe, C., 'Il lungo percorso del dipingere dolcissimo e tanto unito', in: F. Zeri (ed.), Storia dell'arte italiana (Turin: Einaudi, 1983), V, 229-304.

Vybíral, J., 'Why Max Dvořák did not become a Professor in Prague', in: Journal of Art Historiography 17 (2017), https://arthistoriography.files.wordpress.com > 2017/11 > vybiral.

Waetzoldt, W., 'Curt H. Weigelt', in: Mitteilungen des kunsthistorischen Institutes in Florenz V, 1 (1937), 92-93.

Weigelt, C.H., Duccio di Buoninsegna. Studien zur Geschichte der frühsienesischen Tafenmalerei (Leipzig: Karl W. Hiersemann Verlag, 1911).

Weigelt, C.H., 'Duccio', in: U. Thieme and F. Becker (eds.), Allgemeines Lexikon der bildenden Künstler von der Antike bis zur Gegenwart (Leipzig: Seeman, 1914), X, 25-29.

Weigelt, C.H., 'The Madonna Rucellai and the Young Duccio', in: Art in America XVIII, 1 (1929), 3-25; 3 (1930), 105-120.

Weigelt, C.H., Die sienische Malerei des vierzehnten Jahrhunderts (Florence: Edizioni Pantheon, 1930); En. transl. id., Sienese Painting of the Trecento (New York: Harcourt - Brace, 1930).

Weisstein, U., 'Millard Meiss, Giotto and Assisi', in: Art Journal XX, 3 (1961), 184, 186.

White, J., 'The Date of the Legend of St Francis at Assisi', in: The Burlington Magazine XCVIII, 643 (1956), 344-351.

White, J., 'Obituary. Richard Offner', in: The Burlington Magazine CVIII, 758 (1966a), 262, 265.

White, J., Art and Architecture in Italy: 1250 to 1400 (Harmondsworth: Penguin Books, 1966b). White, J., Duccio. Tuscan Art and the Medieval Workshop (London: Thames and Hudson, 1979). 


\section{Bibliography}

Wickhoff, F., 'Über die Zeit des Guido von Siena', in: Mitteilungen des Instituts für österreichische Geschichtsforschung X, 2 (1889), 144-186.

Wiedegand Petzet, H., 'Kurt Bauch', in: Weltkunst XLV (1975), 440.

Winkler, F., 'Curt H. Weigelt', in: Bullettino senese di storia patria VI, 4 (1935), 379-384.

Zanardi, B., Giotto e Pietro Cavallini. La questione di Assisi e il cantiere medievale della pittura a fresco (Milan: Skira, 2002).

Zeri, F., La collezione Federico Mason Perkins (Turin: Allemandi, 1988).

Aikema, B., 'Netherlandish Painting and Early Renaissance Art: Artistic Rapports in a Historiographical Perspective', in: H. Roodenburg (ed.), Cultural Exchange in Early Modern Europe. Vol. IV Forging European Identities, 1400-1700 (Cambridge: Cambridge University Press, 2007), 100-137.

'Albert Mathias Friend, Jr. (1894-1956)', in: Dumbarton Oaks Papers XII (1958), 1-2.

Alexander, J.J.G., 'Carl Nordenfalk, 1907-1992', in: The Burlington Magazine CXXXV, 1078 (1993), 38-39.

Alpers, S., 'Is Art History?' in: Daedalus, CVI, 3 (1977), 1-13.

Alpers, S., The Art of Describing. Dutch Art in the Seventeenth Century (Chicago IL: The University of Chicago Press, 1983).

Anderson, J., 'Giorgione, Titian and the Sleeping Venus', in: N. Pozza (ed.), Tiziano e Venezia, conference proceedings, Venice 27 September-1 October 1976 (Vicenza: Neri Pozza, 1980), 337-342.

Argan, G.C., 'Ideology and Iconology', in: Critical Inquiry II, 2 (1975), 297-305.

Armstrong, C.A.J., 'French Painting in the Time of Jean de Berry. The Late Fourteenth Century and the Patronage of the Duke by Millard Meiss', in: The English Historical Review LXXXIV, 332 (1969), 577-579.

Aronberg Lavin, M., The Eye of the Tiger. The Foundation and Development of the Department of Art and Archaeology, 1883-1923, Princeton University (Princeton NJ: The Art Museum, 1983).

Aronberg Lavin, M., 'The Joy of St. Francis: Bellini's Panel in the Frick Collection', in: Artibus et Historiae XXVIII, 56 (2007), 231-256.

Avril, F., 'La peinture française autour de 1400', in: Revue de l'Art 28 (1975), 40-52.

Avril, F. and Reynaud, N. (eds.), Les manuscrits à peintures en France 1440-1520, exhibition catalogue (Paris: Flammarion, 1993).

Bacon, M., Pragmatism: An Introduction (Oxford: Polity Press, 2012).

Baert, B., Lehmann, A.-S. and Van den Akkerveken, J. (eds.), New Perspectives in Iconology. Visual Studies and Anthropology (Brussels: Academica \& Scientific Publication, 2011).

Bailey, C.B., Building The Frick Collection. An Introduction to the House and Its Collections (London: Scala Publishers, 2006).

Banker, J.R., 'Piero della Francesca. The Commission and Completion of the Sant'Agostino Altarpiece', in: N. Silver (ed.), Piero della Francesca in America: From Sansepolcro to the East Coast, exhibition catalogue (New York: The Frick Collection, 2013), 69-81.

Barron, S. and Eckmann, S. (eds.), Exiles + Emigrés: The Flight of European Artists from Hitler, exhibition catalogue (Los Angeles CA: Los Angeles County Museum of Art, 1997).

Batterson, S.L., Pursuit of Genius. Flexner, Einstein, and the Early Faculty at the Institute for Advanced Study (Wellesley MA: A K Peters/CRC Press, 2006).

Battisti, E., 'Le arti figurative nella cultura di Venezia e di Firenze nel Cinquecento', in: Commentari VI, 4 (1955), 241-253.

Battisti, E., 'Un'antica interpretazione della «Tempesta»', in: Emporium CXXVI (1957), 195201; republ. in: id., Rinascimento e Barocco (Turin: Einaudi, 1960), 146-156.

Battisti, E., Piero della Francesca, 2 vols. (Milan: Istituto Editoriale Italiano, 1971).

Baxandall, M., Giotto and the Orators. Humanist Observers of Painting in Italy and the Discovery of Pictorial Composition 1350-1450 (Oxford: Oxford University Press, 1971). 
Bedaux, J.-B., 'The Reality of Symbols: The Question of Disguised Symbolism in Jan van Eyck's "Arnolfini Portrait"', in: Simiolus XVI, 1 (1986), 5-28.

Bedaux, J.-B., The Reality of Symbols: Studies in the Iconology of Netherlandish Art 14001800 ('s-Gravenhage: Schwartz, SDU, 1990).

Beecher, J., 'Panofsky Examines Roman Subjects in Medieval Art', in: The Harvard Crimson 11 December 1956, http://www.thecrimson.com/article/1956/12/11/panofsky-examines-roman -subjects-in-medieval/.

Beenken, H., 'The Annunciation of Petrus Christus in the Metropolitan Museum and the Problem of Hubert van Eyck', in: The Art Bulletin XIX, 2 (1937), 220-241.

Bellosi, L. (ed.), Pittura di luce. Giovanni di Francesco e l'arte fiorentina di metà Quattrocento, exhibition catalogue (Milan: Electa, 1990).

Bellosi, L., 'Entry', in: G. Agosti and D. Thiébaut (eds.), Mantegna 1431-1506, exhibition catalogue (Paris: Hazan, 2008), 119-123.

Belting, H., The Germans and their Art: A Troublesome Relationship (New Haven, CT, London: Yale University Press, 1998); or. ed. id., Die Deutschen und ibre Kunst: ein schwieriges Erbe (Munich: Beck, 1992).

Benjamin, L., 'Disguised Symbolism Exposed and the History of Early Netherlandish Painting', in: Studies in Iconography 2 (1976), 11-24.

Berenson, B., Venetian Painting in America: The Fifteenth Century (London: G. Bell and Sons, 1916).

Berenson, B., Piero della Francesca or the Ineloquent in Art (New York: Macmillan, 1954); 1st ed. Piero della Francesca o dell'arte non eloquente (Florence: Electa Editrice, 1950).

Białostocki, J., 'Erwin Panofsky (1892-1968): Thinker, Historian, Human Being', in: Simiolus IV, 2 (1970), 68-89.

Białostocki, J., 'A Plea for Internationality', in: Art History I, 4 (1978), v-viii.

Boase, T.S.R., 'French Painting in the Time of Jean de Berry by Millard Meiss', in: Journal of the Royal Society of Arts CXVI, 5147 (1968), 949-950.

Boase, T.S.R., 'French Painting in the Time of Jean de Berry by Millard Meiss', in: Journal of the Royal Society of Arts CXVII, 5157 (1969), 683.

Bober, H., 'Jewels of the Floodlands', in: Saturday Review of Literature (8 May 1954), 38-39.

Bober, H., 'The Gothic Tower and the Stork Club', in: Arts and Sciences I (1962), 1-8.

Bober, P.P., 'The Coryciana and the Nymph Corycia', in: Journal of the Warburg and Courtauld Institutes XL (1977), 223-239.

Boon, K.G., 'Erwin Panofsky's Early Netherlandish Painting', in: Oud Holland LXXII, 3 (1957), 169.

Boon, K.G., 'L.M.J. Delaissé', in: The Burlington Magazine CXIV, 829 (1972), 246-247.

Borchert, T.-H., L'homme au chaperon bleu de Jan van Eyck (Metz: Serpenoise, 2000).

Borchert, T.-H. (ed.), The Age of Van Eyck 1430-1530. The Mediterranean World and Early Netherlandish Painting, exhibition catalogue (London: Thames \& Hudson, 2002).

Brisson, D.W., 'Piero della Francesca's Egg Again', in: The Art Bulletin LXII, 2 (1980), 284-286.

Brockwell, M.W., The Pseudo-Arnolfini Portrait: A Case of Mistaken Identity (London: Chatto \& Windus, 1952).

Brockwell, M.W., The Van Eyck Problem (London: Chatto \& Windus, 1954a).

Brockwell, M.W., 'Maurice W. Brockwell replies to Professor Panofsky', in: The Connoisseur CXXXIII, 538 (1954b), 266-267.

Brush, K., 'German Kunstwissenschaft and the Practice of Art History in America after World War I. Interrelationships, Exchanges, Contexts', in: Marburger Jahrbuch für Kunstwissenschaft XXVI (1999), 7-36.

Brush, K., 'The Unshaken Tree: Walter W.S. Cook on Kunstwissenschaft in 1924', in: D. Johnson and D. Ogawa (eds.), Seeing and Beyond: Essays on Eighteenth-to Twenty-First-Century Art in Honor of Kermit S. Champa (New York: Lang, 2005), 329-360. 


\section{Bibliography}

Burkart, L., “"Die Träumereien einiger kunstliebender Klosterbrüder ...” Zur Situation der Kulturwissenschaftlichen Bibliothek Warburg zwischen 1929 und 1933', in: Zeitschrift für Kunstgeschichte LXIII (2000), 89-119.

Butler, P., 'Illuminated Books of the Middle Ages and Renaissance', in: The Library Quarterly XIX, 4 (1949), 298.

Cain, J., 'Jean Porcher Conservateur en chef du Cabinet des Manuscrits', in: Gazette des BeauxArts s. VI, CV, LXII, 1136 (1963), 171-175.

Calvesi, M., 'La Tempesta di Giorgione come Ritrovamento di Mosé', in: Commentari XIII, 3-4 (1962), 226-255.

Calvesi, M., 'A noir (Melancolia I)', in: Storia dell'Arte 1-2 (1969), 37-96.

Calvesi, M., 'La 'morte di bacio'. Saggio sull'ermetismo di Giorgione', in: Storia dell'Arte 7-8 (1970), 179-233.

Castelfranchi Vegas, L., Italia e Fiandra nella pittura del Quattrocento (Milan: Jaca Book, 1983).

Castelnuovo, E., Un pittore italiano alla corte di Avignone. Matteo Giovannetti e la pittura in Provenza nel secolo XIV (Turin: Einaudi, 1991²; 1st ed. 1962).

Castelnuovo, E. and Ghelardi, M., '97 Battle Road', in: E. Panofsky, Il significato nelle arti visive (Turin: Einaudi, $1996^{2}$ ), xvii-xxxviii.

Chastel, A., L'image dans le miroir (Paris: Gallimard, 1980).

Chastel, A. (ed.), Pour un temps: Erwin Panofsky (Paris: Centre Georges Pompidou, 1983).

Châtelet, A., 'De Jean Porcher à François Avril et Nicole Reynaud: L'enluminure en France entre 1440 et 1520', in: Bulletin Monumental CLII, 1 (1994), 215-226.

Christiansen, K., 'Giovanni Bellini e la maniera devota', in: G. Toscano and F. Valcanover (eds.), Da Bellini a Veronese. Temi di arte veneta (Venice: Istituto Veneto di Scienze, Lettere ed Arti, 2004), 123-146.

Cieri Via, C., Nei dettagli nascosto: per una storia del pensiero iconologico (Rome: La Nuova Italia, 1994).

Cieri Via, C., '1933: fra Europa e Stati Uniti', in: E. Panofsky and F. Saxl, Mitologia classica nell'arte medievale (Turin: Aragno, 2009), v-lviii.

Cieri Via, C., 'Meyer Schapiro ed Erwin Panofsky fra stile e iconologia', in: L. Bortolotti, C. Cieri Via, M.G. Di Monte, M. Di Monte (eds.), Meyer Schapiro e i metodi della storia dell'arte, conference proceedings, Rome 22-24 February 2006 (Rome: Mimesis, 2010), 115-134.

Cieri Via, C., 'Una fortuna planetaria. Erwin Panofsky e la Morgan Library', in: M. Gianandrea, F. Gangemi and C. Costantini (eds.), Il potere dell'arte nel Medioevo. Studi in onore di Mario D’Onofrio (Rome: Campisano, 2014), 839-847.

Cieri Via, C., 'L'iconologia dello stile: un cortocircuito energetico fra Aby Warburg ed Erwin Panofsky', in: A. Barale, F. Desideri and S. Ferretti (eds.), Energia e rappresentazione. Warburg, Panofsky, Wind (Milan - Udine: Mimesis, 2016), 209-242.

Clark, K., Piero della Francesca (London: Phaidon, 1951).

Concasty, M.-L., 'Jean Porcher (1892-1966)', in: Cahiers de civilisation médiévale IX (1966), $275-277$.

Coo, J. de, 'A Medieval Look at the Merode Annunciation', in: Zeitschrift für Kunstgeschichte XLIV, 2 (1981), 114-132.

Cooke, J., 'Nota critica', in: M. Meiss, 'La luce come forma e simbolo in alcuni dipinti del Quattrocento (1945)', in: Annali di Critica d'Arte 7 (2011a), 33-71.

Cooke, J., “'Sonno a Venezia”. Millard Meiss e l'interpretazione iconologica del mito', in: Crepuscoli Dottorali I, 1 (2011b), http://crepuscoli.wordpress.com/2011/03/15/\%E2\% 80\% 9Csonno-a-venezia \%E2\% 80\%9D-millard-meiss-e-1\%E2\% 80\%99interpretazione-iconol ogica-del-mito/.

Cooke, J., 'Nota critica', in: E. Panofsky, 'Imago Pietatis. Un contributo alla storia tipologica dell'Uomo dei dolori e della Maria Mediatrix (1927)', in: Annali di Critica d'Arte 11 (2015), $31-74$. 
Cooke, J., 'Prospettive critiche tra Italia e Stati Uniti attraverso la corrispondenza epistolare tra Millard Meiss e Roberto Longhi', in: C. Galassi (ed.), Critica d'arte e tutela in Italia: figure e protagonisti nel secondo dopoguerra, conference proceedings, Perugia 17-19 November 2015 (Perugia: Aguaplano, 2017), 503-518.

Cooke, J., 'CIHA as the Subject of Art Theory: The Methodological Discourse in the International Congresses of Art History from Post-War Years to the 2000s', in: RIHA Journal 30 September 2018, https://www.riha-journal.org/articles/2018/0199-cooke.

Coser, L.A., Refugee Scholars in America. Their Impact and Their Experiences (New Haven CT - London: Yale University Press, 1984).

Crowe, J.A. and Cavalcaselle, G.B., A History of Painting in North Italy, ed. by T. Borenius, 3 vols. (New York: John Murray, 1912).

'De Artibus Opuscula XL: Essays in Honor of Erwin Panofsky by Millard Meiss', in: Speculum XXXVII, 1 (1962), 145-146.

DaCosta Kaufmann, T., 'American Voices. Remarks on the Earlier History of Art History in the United States and the Reception of Germanic Art Historians', in: Journal of Art Historiography 2 (2010), http://arthistoriography.files.wordpress.com/2011/02/media_152 488_en.pdf.

Davies, M., 'Flemish Founding Fathers', in: Art News LIII, 3 (1954), 25, 57-58.

Davis, E.M. and Snyder, D., 'Piero della Francesca's Madonna of Urbino. A Further Examination', in: Gazette des Beaux-Arts s. VI, LXXV, 1215 (1970), 193-212.

De Ricci, S. and Wilson, W.J. (eds.), Census of Medieval and Renaissance Manuscripts in the United States and Canada, 3 vols. (New York: H.W. Wilson Company, 1935-1940).

Delaissé, L.M.J., 'Enluminure et peinture dans les Pays-Bas. A propos du livre de E. Panofsky Early Netherlandish Painting', in: Scriptorium XI, 1 (1957), 109-118.

Delaissé, L.M.J., 'Millard Meiss, French Painting in the Time of Jean de Berry, Part I', in: The Art Bulletin LII, 2 (1970), 206-212.

Della Terza, D., Da Vienna a Baltimora. La diaspora degli intellettuali europei negli Stati Uniti d'America (Rome: Editori Riuniti, 2001²).

Deneffe, D. and Vanwijnsberghe, D. (eds.), A Man of Vision. Paul Coremans and the Preservation of Cultural Heritage, conference proceedings, Brussels 15-17 June 2015 (Turnhout: Brepols, 2019).

DeWald, E.T., F.F.J., 'Albert Mathias Friend, Jr.', in: Record of the Art Museum. Princeton University XV, 2 (1956), 31.

Didi-Huberman, G., L'image survivante. Histoire de l'art et temps de fantômes selon Aby Warburg (Paris: Editions de Minuit, 2002).

Dufrêne, T., 'A Short History of CIHA', 2007, http://www.esteticas.unam.mx/CIHA/documents /Short_History_of_CIHA.pdf.

Dussler, L., Giovanni Bellini (Frankfurt: Prestel, 1935).

Eisler, C.T., 'The Golden Christ of Cortona and the Man of Sorrows in Italy', in: The Art Bulletin LI, 2 (1969), 107-118; LI, 3 (1969), 233-246.

Eisler, C., 'American Art History, God shed His grace on thee, or, the Good, the True and the Beautiful through the Bicentennial', in ArtNews LXXV, 5 (1976), 64-73.

Eisler, C.T., 'Millard Meiss, French Painting in the Time of Jean de Berry', in: The Art Bulletin LXIII, 2 (1981), 328-332.

Elsner, J. and Lorenz, K., 'The Genesis of Iconology', in: Critical Inquiry XXXVIII, 3 (2012), 483-512.

Emison, P., 'Asleep in the Grass of Arcady: Giulio Campagnola's Dreamer', in: Renaissance Quarterly XV, 2 (1992), 271-292.

Emmens, J.A. and Schwartz, G., 'Erwin Panofsky as a Humanist', in: Simioulus II, 3 (19671968), 109-113.

Fahy, C. and Moores, J.D., 'A list of the publications of Roberto Weiss (1906-1969)', in: Italian Studies XXIX (1974), 1-11. 


\section{Bibliography}

Ferber, S., 'French Painting in the Time of Jean de Berry by Millard Meiss', in: Speculum XLV, 3 (1970), 481-483.

Fermi, L., Illustrious Immigrants: The Intellectual Migration from Europe, 1930-41 (Chicago IL: The University of Chicago Press, 1968).

Fierens, P. (eds.), I Fiamminghi e l'Italia. Pittori italiani e fiamminghi dal XV al XVIII secolo, exhibition catalogue (Venice: Casa Editrice Arte Veneta, 1951).

Firestone, G., 'The Sleeping Christ-Child in the Renaissance', in: Marsyas II (1942), 43-62.

Fleckner, U. and Mack, P. (eds.), The Afterlife of the Kulturwissenschaftliche Bibliothek Warburg: The Emigration and the Early Years of the Warburg Institute in London (Berlin: De Gruyter, 2015).

Fleming, D. and Bailyn, B. (eds.), The Intellectual Migration. Europe and America, 1930-1960 (Cambridge MA: Harvard University Press, 1969).

Fleming, J.V., From Bonaventure to Bellini: An Essay in Franciscan Exegesis (Princeton, NJ: Princeton University Press, 1982).

Förster, O.H., 'Erwin Panofsky, Early Netherlandish Painting', in: Wallraf-Richartz-Jabrbuch XVII (1955), 257.

Forsyth, G.H., 'Albert M. Friend, Jr.', in: College Art Journal XLI, 4 (1957), 340-341.

Frank, G. and Miner, D., Proverbes en rimes. Text and Illustrations of the Fifteenth Century from a French Manuscript in the Walters Art Gallery Baltimore (Baltimore MD: The John Hopkins Press, 1937).

Frankfurter, A., 'In Memory of Walter W.S. Cook', in: ArtNews LXI, 7 (1962), 27.

Frinta, M.S., 'French Painting in the Time of Jean de Berry by Millard Meiss', in: Art Journal XXX, 1 (1970), 106, 110.

Fry, R., 'The Old Masters at Burlington House', in: The Nation X (20 January 1912), 657.

Gamba, C., Giovanni Bellini (Milan: Hoepli, 1937).

Gandolfo, F., Il 'Dolce Tempo'. Mistica, Ermetismo e Sogno nel Cinquecento (Rome: Bulzoni Editore, 1978).

Gentili, A., Da Tiziano a Tiziano. Mito e allegoria nella cultura veneziana del Cinquecento (Milan: Feltrinelli, 1980).

Gentili, A., 'Tiziano, Panofsky e l'iconologia in Italia', in: E. Panofsky, Tiziano: Problemi di iconografia (Venice: Marsilio, 1992), 197-223.

Ghisalberti, F., 'Medieval Biographies of Ovid', in: Journal of the Warburg and Courtauld Institutes IX (1946), 10-59.

Gilbert, A.H. and Janson, H.W., 'Erwin Panofsky, Studies in Iconology', in: The Art Bulletin XXII, 3 (1940), 172-175.

Gilbert, C.H., 'On Subject and Non-Subject', in: The Art Bulletin XXIV, 3 (1952), 202-216.

Gilbert, C., 'Letter to the Editor', in: The Art Bulletin XXXV, 4 (1953), 329-330.

Gilbert, C., Change in Piero della Francesca (Locust Valley NY: J.J. Augustin, 1968).

Gilbert, C.H., 'Renaissance Art and Its Scholars', in: id. (ed.), Renaissance Art (New York: Harper \& Row, 1970), xi-xxi.

Gilbert, C., “"The Egg Reopened” Again', in: The Art Bulletin LVI, 2 (1974), 252-258.

Ginzburg, C., The Enigma of Piero: Piero della Francesca: The Baptism, The Arezzo Cycle, The Flagellation (London: Verso, 1985); or. ed. id., Indagini su Piero. Il Battesimo, il ciclo di Arezzo, la Flagellazione di Urbino (Turin: Einaudi, 1981).

Ginzburg, C., 'From Aby Warburg to E.H. Gombrich: A Problem of Method, in: id., Clues, Myths, and the Historical Method (Baltimore MD: John Hopkins University Press, 20132), 16-53, 170-194; or. ed. id., 'Da A. Warburg a E.H. Gombrich. Note su un problema di metodo (1966)', in: id., Miti emblemi spie (Turin: Einaudi, 1986), 29-106.

Godwin, F.G., 'Erwin Panofsky, Early Netherlandish Painting', in: College Art Journal XV, 1 (1955), 70-72.

Goebel, E. and Weigel, S. (eds.), 'Escape to Life'. German Intellectuals in New York: A Compendium on Exile after 1933 (Berlin - Boston MA: De Gruyter, 2013). 